\title{
Mixed layer variability and chlorophyll $a$ biomass in the Bay of Bengal
}

\author{
J. Narvekar and S. Prasanna Kumar \\ CSIR-National Institute of Oceanography, Dona Paula, Goa 403 004, India \\ Correspondence to: S. Prasanna Kumar (prasanna@ nio.org)
}

Received: 3 September 2013 - Published in Biogeosciences Discuss.: 24 October 2013

Revised: 13 May 2014 - Accepted: 3 June 2014 - Published: 22 July 2014

\begin{abstract}
The mixed layer is the most variable and dynamically active part of the marine environment that couples the underlying ocean to the atmosphere and plays an important role in determining the oceanic primary productivity. We examined the basin-scale processes controlling the seasonal variability of mixed layer depth in the Bay of Bengal and its association with chlorophyll using a suite of in situ as well as remote sensing data. A coupling between mixed layer depth and chlorophyll was seen during spring intermonsoon and summer monsoon, but for different reasons. In spring intermonsoon the temperature-dominated stratification and associated shallow mixed layer makes the upper waters of the Bay of Bengal nutrient depleted and oligotrophic. In summer, although the salinity-dominated stratification in the northern Bay of Bengal shallows the mixed layer, the nutrient input from adjoining rivers enhance the surface chlorophyll. This enhancement is confined only to the surface layer and with increase in depth, the chlorophyll biomass decreases rapidly due to reduction in sunlight by suspended sediment. In the south, advection of high salinity waters from the Arabian Sea and westward propagating Rossby waves from the eastern Bay of Bengal led to the formation of deep mixed layer. In contrast, in the Indo-Sri Lanka region, the shallow mixed layer and nutrient enrichment driven by upwelling and Ekman pumping resulted in chlorophyll enhancement. The mismatch between the nitrate and chlorophyll indicated the inadequacy of present data to fully unravel its coupling to mixed layer processes.
\end{abstract}

\section{Introduction}

The upper ocean experiences large spatio-temporal variability compared to the rest of the ocean and hence it forms an important region for understanding both short-term and longterm changes including climate change. The intense mixing in the upper ocean by heat, momentum and freshwater flux results in the formation of a homogeneous layer with nearly uniform properties known as the mixed layer. It is this layer that couples the underlying ocean to the atmosphere through the transfer of mass and energy. The heat stored in the mixed layer regulates the air-sea exchange process including convection and cyclone genesis. In addition, the bulk of the oceanic biological productivity critically depends on the physical and chemical changes taking place within this layer. Spatially, the mixed layer thickness increases from a few tens of metres at the Equator to a few hundreds of metres at the poles (Monterey and Levitus, 1997), while temporally it could vary from diurnal to interannual timescales (Weller and Farmer, 1992; Brainerd and Gregg, 1995; Kara et al., 2003). However, within a given geographical region, such as the tropics, the structure and variability of mixed layer largely depends on the regional oceanographic characteristics and atmospheric forcing.

The Bay of Bengal situated in the eastern part of the northern Indian Ocean is a tropical basin, which is landlocked in the north and is forced by a semi-annually reversing monsoon wind system. The strongest winds occur during summer monsoon (June-September) when the southwesterly winds bring humid maritime air mass into the Bay of Bengal. In contrast, during winter monsoon (NovemberFebruary), the winds are weak and from northeasterly direction. These northeast trade winds bring cool and dry continental air mass to the Bay of Bengal. The unique feature 
of the Bay of Bengal is the large seasonal freshwater influx from rivers $\left(1.625 \times 10^{12} \mathrm{~m}^{3} \mathrm{yr}^{-1}\right.$, Subramanian, 1993) as well as excess precipitation over evaporation $\left(\sim 2 \mathrm{~m} \mathrm{yr}^{-1}\right.$, Prasad, 1997), which makes the waters of the upper layers less saline and highly stratified. This fresh water input leads to the formation of a strong halocline within the upper isothermal layer known as "barrier layer" (Lukas and Linderstrom, 1991; Sprintall and Tomczak, 1992).

In the past several studies attempted to understand the mixed layer variability in the Indian Ocean including Bay of Bengal. There exist a few climatologies of the mixed layer depth for the tropical Indian Ocean (Colborn, 1975; Robinson et al., 1979; Levitus, 1982; Hastenrath and Greisher, 1989; Rao et al., 1989). Based on the time series data collected during MONSOON-77 and MONEX-79, Gopalakrishna et al. (1988) studied the influence of wind on the variability of the mixed layer in the northern Indian Ocean during different phases of the summer monsoon. Using global ocean temperature climatology, Rao and Sivakumar (2000) studied the near surface thermal structure and heat budget of the mixed layer of the tropical Indian Ocean including Bay of Bengal. Han et al. (2001) showed that in the regions where precipitation exceeds evaporation the mixed layer was found to be thin because of decreased entrainment and increased barrier layer. While comparing the total kinetic energy available for mixing in the Arabian Sea and the Bay of Bengal, Shenoi et al. (2002) stated that the shallow mixed layer depth in the Bay of Bengal during the summer monsoon is primarily driven by a combination of weaker winds and strong near-surface stratification. Subsequently, Vinayachandran et al. (2002) argued that strong stratification associated with the barrier layer curtails the vertical mixing leading to the formation of a shallow mixed layer. In contrast, with help of a one-dimensional turbulent closure model Prasad (2004) studied the physical mechanism governing the seasonal evolution of mixed layer depth along two transects along the central Arabian Sea and Bay of Bengal and concluded that the surface forcing controls mixed layer depth in the Bay of Bengal rather than the vertical salinity stratification. Rao and Sivakumar (2003), using climatological data, showed that incorporation of salinity reduces the thickness of the mixed layer and horizontal advection dominates over the local fresh water flux in producing the large variability in surface salinity in winter while fresh water flux overwhelms advection during summer. Narvekar and Prasanna Kumar (2006) examined the seasonal cycle of the mixed layer in the central Bay of Bengal using a more comprehensive data set including Argo data and argued that advection of Arabian Sea high salinity water mass and Rossby wave propagation are important in altering the mixed layer depth. Further, they showed a strong coupling between chlorophyll distribution and mixed layer depth during spring intermonsoon. Using a global general circulation model de Boyer Montegut et al. (2007) studied the mixed layer heat budget of the Bay of Bengal as a part of the northern Indian Ocean and stated that the salinity stratification plays a clear role in maintaining a high winter SST (sea surface temperature) in the Bay of Bengal while the presence of freshwater near the surface allows heat storage below the surface layer that can later be recovered by entrainment warming during winter cooling. More recently, Keerthi et al. (2012) studied the interannual variability of the mixed layer in the tropical Indian Ocean and its link to climate modes using eddy permitting numerical simulation and in situ hydrographic data.

All of the above studies examined the variability of the mixed layer in the context of wind-mixing, net heat flux and fresh water flux. Most of them used monthly mean climatology of in situ data to address the mixed layer variability over the Indian Ocean, of which Bay of Bengal forms a part. The rest of the study used in situ data collected from a limited spatial and temporal coverage in the Bay of Bengal during a particular cruise. Though the above studies yielded a fairly good understanding of the processes controlling the mixed layer variability in the Bay of Bengal, there are several aspects which are yet to be addressed such as role of advection and remote forcing. More importantly, we do not yet understand with sufficient details the role of the mixed layer in regulating the basin-wide variability in chlorophyll biomass and primary productivity. It is in this context that the present paper attempts to understand (1) processes controlling basin-wide variability of the mixed layer and (2) coupling between mixed layer and chlorophyll biomass in the Bay of Bengal on a seasonal scale. In the present study using a more comprehensive quality-controlled hydrographic data and atmospheric data we explore the role of local forcing via heat, momentum and fresh water fluxes and remote forcing via propagating waves and advection of high salinity waters from the Arabian Sea in controlling mixed layer variability on a seasonal timescale and its coupling to the chlorophyll biomass.

\section{Data and methodology}

In order to study the seasonal variability of the mixed layer in the Bay of Bengal in response to the local and remote forcing and its coupling to basin-scale distribution of chlorophyll, a suite of both in situ and remote sensing data pertaining to oceanographic and atmospheric parameters were used. The domain within which both the oceanographic and meteorological data were extracted were for the regions Equator$25^{\circ} \mathrm{N}$ latitude and $75^{\circ}-100^{\circ} \mathrm{E}$ longitude.

\subsection{Hydrographic data}

The hydrographic data pertaining to temperature and salinity was extracted from the following three sources:

1. The World Ocean Database 2005 (WOD05) (Boyer et al., 2006) contained temperature and salinity data from Hydro-cast for the period 1919-2000 
and conductivity-temperature-depth (CTD) profiles for the period 1972-2003 (http://www.nodc.noaa.gov/OC5/ WOD05/pr_wod05.html).

2. The responsible National Oceanographic Data Center (RNODC) at National Institute of Oceanography (CSIR-NIO), Goa, which contained temperature and salinity data from Hydro-cast for the period 1972-1996 and CTD profiles for the period 1979-2006. All the data were collected on board Indian research ships.

3. Argo data which contained the temperature and salinity profiles for the period 2002-2007 were extracted from http://www.usgodae.org/argo/argo.html.

In all 7197 profiles of temperature and salinity from Hydro-cast, 2714 profiles from CTD and 4569 profiles from Argo were extracted. These profiles were subjected to the following quality control procedures to obtain quality data for further analysis.

At first all the profiles with depth less than $50 \mathrm{~m}$ were eliminated, as the objective of the study was to determine mixed layer depth, which may exceed $50 \mathrm{~m}$. The remaining data were physically examined and duplicate profiles as well as those with obvious errors were excluded. After the quality control, the total number of Hydro-cast profiles was reduced to 5328 (882 RNODC \& 4446 WOD05), CTD profiles to 2656 (1803 RNODC \& 853 WOD05) and Argo profiles to 4203. From the quality checked data the spatial distribution of total number of temperature and salinity profiles available on a $1^{\circ}$ latitude by $1^{\circ}$ longitude grid is presented in Fig. 1, while the total number of profiles for each month is given in Table 1. From the quality-controlled temperature and salinity profiles, density (sigma- $t$ ) was calculated (UNESCO, 1981) up to a depth of $500 \mathrm{~m}$. This data was further used to prepare the monthly mean climatology of temperature, salinity and sigma- $t$ on a $1^{\circ}$ latitude by $1^{\circ}$ longitude grid. These profiles were used to determine mixed layer depth (MLD).

In order to determine the mixed layer depth one could either specify a difference in temperature or density (sigma- $t$ ) from the surface value (Wyrtki, 1964; Levitus, 1982; Schneider and Muller, 1990) or specify a gradient in temperature or density (sigma- $t$ ) (Bathen, 1972; Lukas and Lindstrom, 1991) depending upon the vertical structure of temperature, salinity and sigma- $t$ of the region. An examination of the vertical profiles of temperature, salinity and density (sigma- $t$ ) at two locations representing the northern $\left(19^{\circ} \mathrm{N}, 89^{\circ} \mathrm{E}\right)$ and southern $\left(9^{\circ} \mathrm{N}, 89^{\circ} \mathrm{E}\right)$ Bay of Bengal during February (winter) and August (summer) showed that in the southern part of the Bay of Bengal the isothermal, isohaline and isopycnal layers, in general, coincided in the upper ocean irrespective of the season (Fig. 2, left panels). In the northern part of the Bay of Bengal there was practically no isohaline layer in the vertical profile of salinity and the salinity rapidly increased within the isothermal layer (Fig. 2, right panels). However, at times the salinity profile showed a thin isohaline layer in

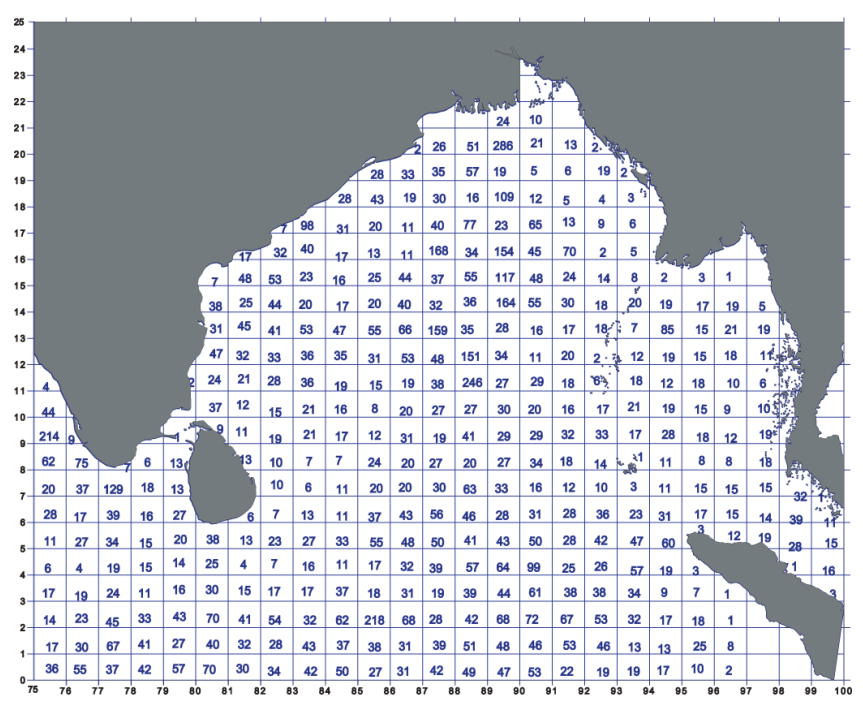

Figure 1. Spatial distribution of total number of temperature and salinity profiles available on a $1^{\circ}$ latitude by $1^{\circ}$ longitude grid.

Table 1. Total number of temperature and salinity profiles in the Bay of Bengal for each month from January to December.

\begin{tabular}{ll}
\hline Month & $\begin{array}{l}\text { Total no. } \\
\text { of profiles }\end{array}$ \\
\hline January & 981 \\
February & 1079 \\
March & 733 \\
April & 769 \\
May & 856 \\
June & 750 \\
July & 1279 \\
August & 1302 \\
September & 996 \\
October & 890 \\
November & 920 \\
December & 1026 \\
\hline
\end{tabular}

the upper water column (not shown). In view of the above, in the present study we defined MLD as the depth at which the density (sigma- $t$ ) exceeds the surface value by $0.2 \mathrm{~kg} \mathrm{~m}^{-3}$. The monthly mean temperature, salinity and density (sigma$t$ ) profiles were interpolated on to a $1 \mathrm{~m}$ depth interval by using the cubic spline method and MLD was determined numerically. The temperature and salinity data was further used for the computation of the static stability parameter following Pond and Pickard (1983):

$E=-\frac{1}{\rho} \frac{\partial \rho}{\partial z}$

where $E$ is the static stability parameter $\left(\mathrm{m}^{-1}\right), \rho$ is the density $\left(\mathrm{kg} \mathrm{m}^{-3}\right)$ of the water and $z$ is the depth $(\mathrm{m})$. 

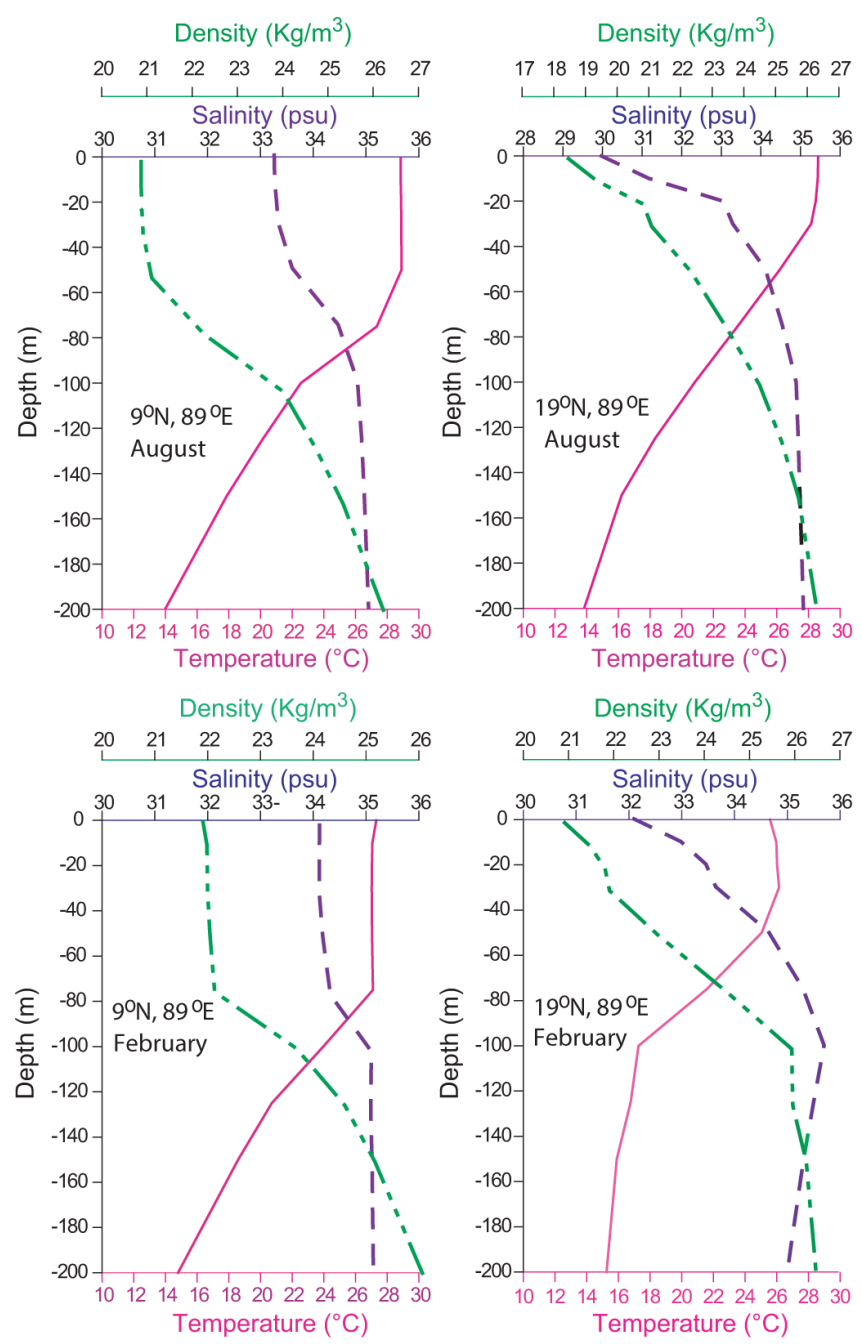

Figure 2. Vertical profiles of temperature, salinity and density (sigma- $t$ ) at two locations representing the northern $\left(19^{\circ} \mathrm{N}, 89^{\circ} \mathrm{E}\right)$ and southern $\left(9^{\circ} \mathrm{N}, 89^{\circ} \mathrm{E}\right)$ Bay of Bengal during February (winter) and August (summer).

\subsection{Nitrate and chlorophyll $a$ data}

The nitrate profiles for the present study were obtained from the WOD05 and RNODC. The former contained the nitrate data for the period 1906-1999 while latter had the data for the period 1973-2006. The total number of nitrate profiles extracted from the above sources was 7406 . From these the duplicate profiles were removed first and then the rest of the profiles were physically checked for any obvious ambiguity, which was removed subsequently. The quality control procedure reduced the total number of profiles to 2653 . The number of profiles available at each of the $1^{\circ}$ latitude $\times 1^{\circ}$ longitude grid is shown in Fig. 3a.

The chlorophyll $a$ profiles were taken from RNODC, which contained data for the period 1951-2006. The total number of chlorophyll $a$ profiles was 1060 and after the qual-
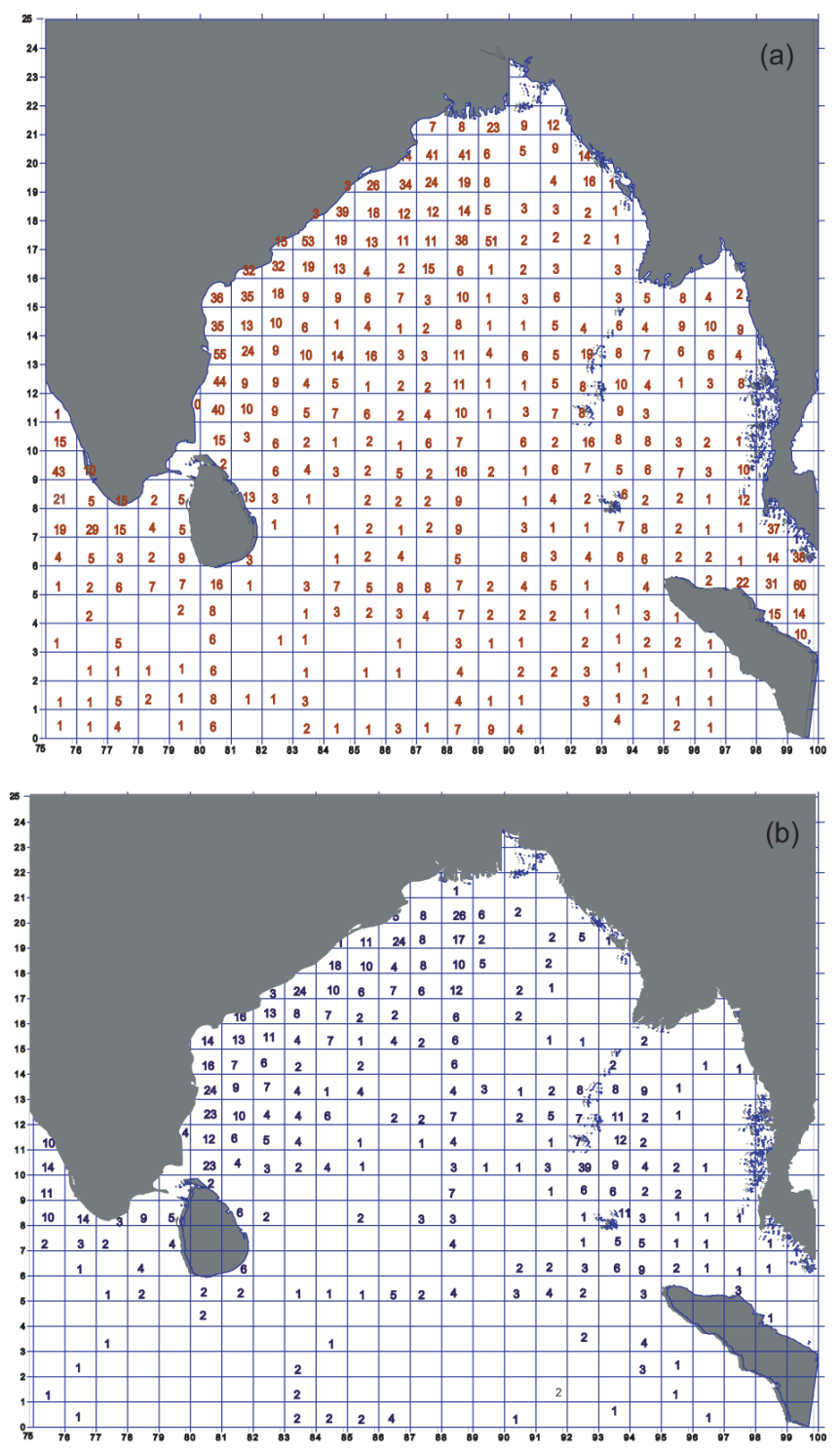

Figure 3. Total number of profiles of (a) nitrate and (b) chlorophyll $a$ available at each of the $1^{\circ}$ latitude $\times 1^{\circ}$ longitude grid.

ity control procedure, similar to that of nitrate, the number of profiles reduced to 1030 . The number of chlorophyll $a$ profiles available in each cell of the $1^{\circ}$ latitude $\times 1^{\circ}$ longitude grid is shown in Fig. 3b.

Since the total number of nitrate and chlorophyll $a$ profiles in each of the $1^{\circ}$ grid itself was less, these data were grouped together in time to produce seasonal climatology. The seasons considered for this purpose were defined as

spring intermonsoon: March-May,

summer monsoon: June-August,

fall intermonsoon: September-October,

winter monsoon: November-February. 
Since spatial coverage of data during fall intermonsoon was very poor and was confined to the western Bay of Bengal, this season was not considered.

\subsection{River runoff data}

The monthly mean climatology of river discharge of six major rivers - Ganges, Brahmaputra, Irrawaddy, Godavari, Krishna and Cauvery - were taken from Global Runoff Data Centre, Germany (http://grdc.bafg.de/servlet/is/2781).

\subsection{Atmospheric data}

Meteorological data were extracted from the National Oceanographic Centre (NOC), Southampton, climatology (formerly Southampton Oceanographic Centre, SOC) (http: //www.noc.soton.ac.uk/ooc/CLIMATOLOGY/noc11.php) in the study domain $\left(0-25^{\circ} \mathrm{N}\right.$ and $\left.75-100^{\circ} \mathrm{E}\right)$ for the period from 1980 to 2005 . It contained the monthly mean climatology of incoming short wave radiation, wind speed, evaporation, precipitation and net heat flux on a $1^{\circ}$ longitude by $1^{\circ}$ latitude grid.

\subsection{Remote sensing data}

Since the in situ chlorophyll data was limited in both space and time, chlorophyll pigment concentrations derived from global $9 \mathrm{~km}$ monthly mean imagery of Sea-viewing Wide Field-of-view Sensor (SeaWiFS) for the period from September 1997 to December 2007 (http://reason.gsfc.nasa.gov/ OPS/Giovanni/ocean.seawifs.shtml). From these data the climatological seasonal means were calculated for spring intermonsoon, summer monsoon, fall intermonsoon and winter monsoon.

Merged sea-level anomalies of Topex/Poseidon ERS1/2 series satellites obtained from the AVISO live access server (http://las.aviso.oceanobs.com) was also used for the period from October 1992 to January 2006, which gives 7-day snapshots having a spatial resolution of one-third of a degree, to prepare a monthly mean climatology of sea-level anomalies. From the sea-level height anomalies, velocities were computed assuming the geostrophic relation (Pond and Pickard, 1983)

$2 \Omega \sin (\varphi) \times V=g \tan (i)$,

where $\Omega$ is Earth's angular velocity, $\varphi$ is the latitude, $V$ is the velocity and $\tan (i)$ is the slope of the sea surface.

\section{Results}

We first examined the spatio-temporal variability of MLD by analysing the monthly mean climatology. To understand the processes affecting the mixed layer variability we examined the monthly mean climatology of SST, sea surface salinity (SSS), incoming short wave radiation, net heat flux (NHF), wind speed (WS), momentum flux (wind-stress curl) and the fresh water flux (evaporation-precipitation; $E-P$ ) in tandem with MLD. For brevity we have presented the monthly mean climatology of all the above parameters except MLD in the Appendix. In the main text we present the monthly mean climatology of MLD superimposed with relevant parameters that are responsible for the observed variability in the mixed layer and discussed the seasonal cycle. Finally, we examine the seasonal variability of chlorophyll and nutrients to understand the possible link between them and mixed layer.

\subsection{Spring intermonsoon}

The mixed layer depth during the spring intermonsoon (March-April-May; Fig. 4a-c) was the shallowest in the Bay of Bengal compared to the rest of the months (Appendix Fig. A1), particularly during March and April. It varied between 10 and $25 \mathrm{~m}$ except in the southwestern region in March and April and near the western boundary in April. In May, however, the shallow MLD was confined to the region north of $16^{\circ} \mathrm{N}$ (Fig. 4c). Another region of comparatively shallow MLD $(\sim 25 \mathrm{~m})$ was seen in a band between 6 and $9^{\circ} \mathrm{N}$ encompassing peninsular India and Sri Lanka. The rest of the basin, however, showed slightly deeper MLD (30$35 \mathrm{~m})$.

The observed MLD variability could be understood in the light of the prevailing ocean-atmospheric conditions. The incoming solar radiation peaked during March-April (280 $290 \mathrm{~W} \mathrm{~m}^{-2}$, Appendix Fig. A4) with a corresponding peak in the net heat flux (150-160 $\mathrm{W} \mathrm{m}^{-2}$, Appendix Fig. A5). The basin-wide winds were the weakest during this period (4$5 \mathrm{~m} \mathrm{~s}^{-1}$, Appendix Fig. A6), except near the western boundary in April where a core of high wind speed as well as negative wind stress curl was noticed (Fig. 4b). Note that the peak solar heating and subsequent highest net heat gain by the ocean lead to thermal stratification. In addition, low salinity waters in the northern Bay of Bengal (north of $18^{\circ} \mathrm{N}$ ) with salinity less than 32.5 psu (practical salinity units; Appendix Fig. A3) during March-April lead to strong haline stratification, specially in the upper $20 \mathrm{~m}$, as is evident from the vertical profiles of the stability parameter (Fig. 4d). Thus, during spring intermonsoon the weak winds were unable to break the strong thermohaline stratification to drive deep wind mixing and hence led to the formation of a shallow mixed layer.

In the south, a comparatively deeper mixed layer $(\sim 35 \mathrm{~m})$ seen west of $90^{\circ} \mathrm{E}$ appears to be linked to the prevailing salinity and wind conditions. The presence of relatively high salinity waters (> $34.5 \mathrm{psu}$ ) during spring intermonsoon (Appendix Fig. A3) made the upper water column, specially the upper $30 \mathrm{~m}$, less stable compared to the north (Fig.4d) and the moderate winds (Appendix Fig. A6) were able to initiate greater mixing which led to the observed deep MLD. The comparatively deeper MLD along the western boundary $(>25 \mathrm{~m})$ in April was driven by the strong negative wind stress curl $\left(\sim-20 \times 10^{-8} \mathrm{~Pa} \mathrm{~m}^{-1}\right.$, Fig. 4b). However, the 

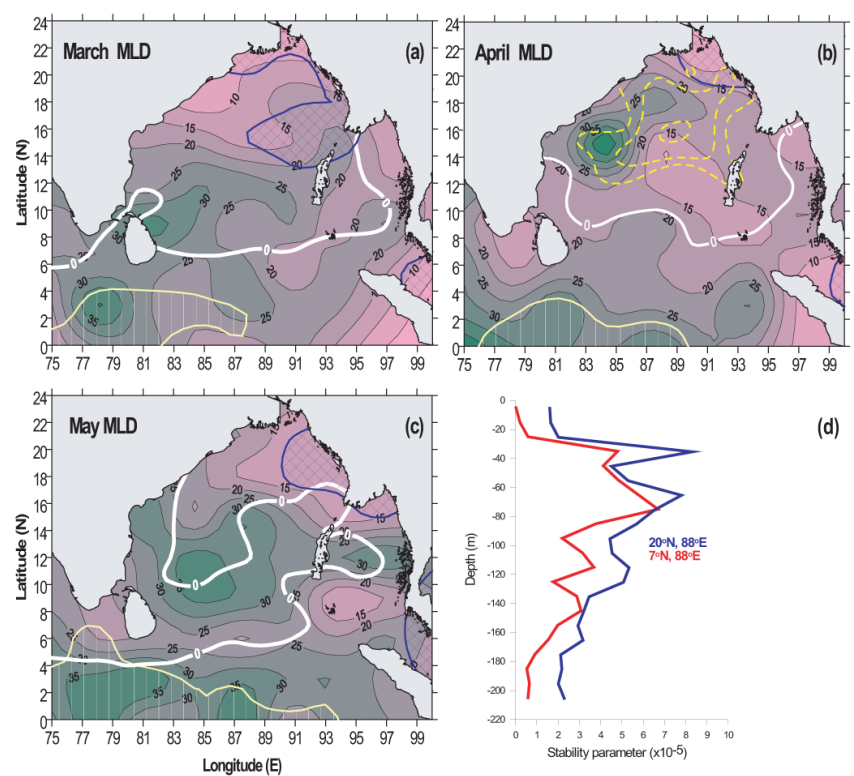

Figure 4. Monthly mean climatology of mixed layer depth (m) in the Bay of Bengal during spring intermonsoon in (a) March, (b) April and (c) May, and (d) vertical profiles of the upper ocean stability parameter $\left(E, \mathrm{~m}^{-1}\right)$ at $20^{\circ} \mathrm{N}, 88^{\circ} \mathrm{E}$ (blue line) and $7^{\circ} \mathrm{N}, 88^{\circ} \mathrm{E}$ (red line) in April. In (a-c) the blue crosshatch represents the region where salinity is less than 32 psu, while vertical lines within the thin yellow solid line represent the region where the salinity is greater than $34.5 \mathrm{psu}$. The thick broad white line indicates the zero wind stress curl and the region south of it (equatorward) have positive wind stress curl. The yellow broken contours in (b) indicate the negative wind stress curl $\left(-10\right.$ to $\left.-20 \times 10^{-8} \mathrm{~Pa} \mathrm{~m}^{-1}\right)$ with increasing magnitude towards the centre.

comparatively shallow MLD in a band between 6 and $10^{\circ} \mathrm{N}$ east of Sri Lanka and the southern tip of India during AprilMay cannot be explained in the context of the prevailing ocean atmospheric condition alone and hence we have examined the role of planetary waves such as Rossby waves in a separate section.

\subsection{Summer monsoon}

The mixed layer during summer monsoon (June-JulyAugust) was the deepest. With the progress of summer monsoon from June to August the mixed layer in most parts of the Bay of Bengal and in the region between the Equator and $6^{\circ} \mathrm{N}$ was deep (Fig. 5a-c). However, along the western boundary and in the northern and eastern parts of the bay the MLD was shallow. Similarly, the region around peninsular India and Sri Lanka also showed the presence of a shallow mixed layer. With the progress of summer monsoon, the region of shallow mixed layer around Sri Lanka showed a progressive eastward extension with time. The observed pattern of MLD variation could be explained in the following manner. Though the wind speeds were the highest during summer monsoon in the entire basin (Appendix Fig. A6), the MLD
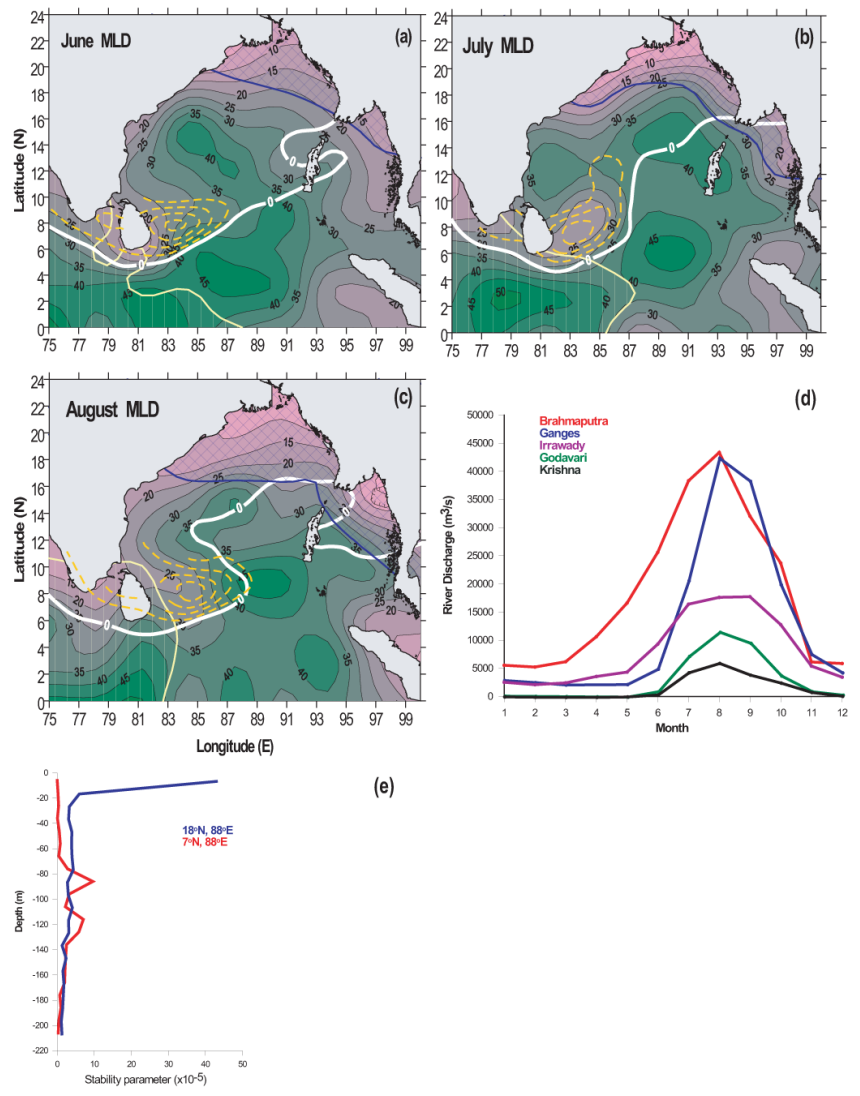

(e)

Figure 5. Monthly mean climatology of mixed layer depth (m) in the Bay of Bengal during summer in (a) June, (b) July and (c) August; (d) monthly mean river discharge climatology of the Ganges, Brahmaputra, Irrawaddy, Godavari and Krishna rivers; and (e) vertical profiles of the upper ocean stability parameter $\left(E, \mathrm{~m}^{-1}\right)$ at $18^{\circ} \mathrm{N}, 88^{\circ} \mathrm{E}$ (blue line) and $7^{\circ} \mathrm{N}, 88^{\circ} \mathrm{E}$ (red line) in the Bay of Bengal during July. In (a-c) the blue crosshatch represents the region where salinity is less than 32 psu, while vertical lines within the thin yellow solid line represent the region where the salinity is greater than $34.5 \mathrm{psu}$. The thick broad white line indicates the zero wind stress curl and the region south of it (equatorward) have negative wind stress curl. The yellow broken contours indicate the positive wind stress curl ( 5 to $20 \times 10^{-8} \mathrm{~Pa} \mathrm{~m}^{-1}$ ) with increasing magnitude towards the centre.

were the shallowest in the northern Bay of Bengal $(<10 \mathrm{~m})$. An examination of $E-P$ showed that it was negative and the highest of all the season, implying excess precipitation, in excess of $440 \mathrm{~mm} \mathrm{month}^{-1}$ in the northern Bay of Bengal (Appendix Fig. A8). In addition to the oceanic precipitation, the influx of freshwater from the rivers adjoining the Bay of Bengal may also contribute towards freshening of the surface waters of the bay. An examination of the monthly mean climatology of river discharge of five major rivers - Ganges, Brahmaputra, Irrawaddy, Godavari, and Krishna - showed that the freshwater discharge dominated from July to October (Fig. 5d). The spreading of low salinity waters $(<32 \mathrm{psu})$ were seen from the northern Bay of Bengal towards the south 
and also along eastern and western boundaries (see the blue crosshatch in Fig. 5a-c) with the progress of summer monsoon. Note that the upper ocean was very warm with SST in excess of $28.5^{\circ} \mathrm{C}$ (Appendix Fig. A2). These warm and low salinity waters contributed towards strengthening the stratification of the upper ocean as could be inferred from the stability parameter (Fig. 5e). Thus, though the winds were the strongest of all the seasons, they were unable to break the stratification and initiate wind-driven mixing to deepen the mixed layer. However, the shallow MLD seen around Sri Lanka, irrespective of the excess evaporation (Appendix Fig. A8), was not driven by the thermohaline stratification but due to the positive wind stress curl (yellow broken contours in Fig. 5a-c). The positive wind stress curl was seen developing in May, peaks in June and collapses by September (Appendix Fig. A7). This positive wind stress curl drives an upward Ekman pumping and this led to the observed shallow mixed layer around Sri Lanka.

The band of deep mixed layer seen extending from the southwestern region of the study area into the central Bay of Bengal was the indication of the advection of high salinity waters from the Arabian Sea. To explore this aspect further, we examined the monthly mean climatology of the SSS, which showed progressive advection of high salinity waters from the Arabian Sea into the central Bay of Bengal dominantly from June to August (Appendix Fig. A3). A plot of basin-wide surface mean salinity overlaid with a geostrophic current vector derived from the mean sea level anomaly and mixed layer depth (Fig. 6) for the same period clearly depict that the advection of the high salinity Arabian Sea water takes place under the influence of the summer monsoon current (SMC) that prevails during this time of the year. Note that the region of deepest mixed layer lies within the high salinity water and is oriented in the direction of advection. This high salinity waters reduced the upper ocean stratification as could be inferred from the stability parameter (Fig. 5e). Thus, the strong winds of the summer monsoon combined with the less stratified upper ocean due to the intrusion of high salinity waters from the Arabian Sea were able to drive strong wind-driven mixing. This led to the formation of deep MLD in summer. In addition to this, the negative wind stress curl in the central and western Bay of Bengal also contributed to the observed deep MLD.

\subsection{Fall intermonsoon}

As the summer monsoon tapers off and the fall intermonsoon sets in, the shallow MLD region in the northern Bay of Bengal, which was confined to north of $18^{\circ} \mathrm{N}$, was seen extending southward and eastward, while the southern part of the bay showed a deep mixed layer (Fig. 7). This could be explained in the context of changing atmospheric forcing from summer monsoon to fall intermonsoon. The short wave radiation as well as net heat flux showed a secondary heating of the upper ocean during fall intermonsoon (Ap-

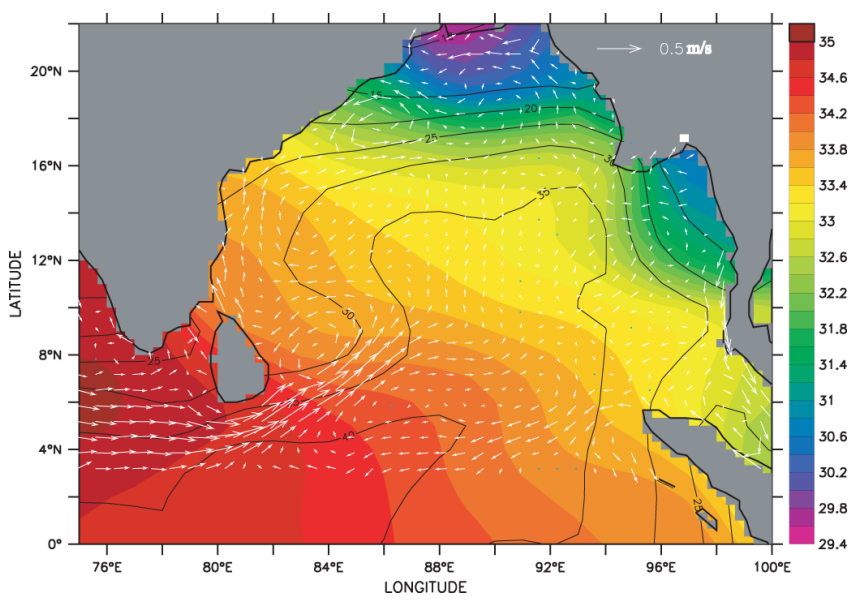

Figure 6. Mean surface salinity (psu, shading) overlaid with geostrophic current $\left(\mathrm{m} \mathrm{s}^{-1}\right.$, white vectors) derived from mean sea level anomaly and mixed layer depth ( $\mathrm{m}$, black contours) for the period June-August.

pendix Figs. A4, A5) and accordingly the SST was in excess of $29^{\circ} \mathrm{C}$ in October (Appendix Fig. A2). Though the $E-P$ showed a rapidly decreasing precipitation (Appendix Fig. A8) during this period, the surface salinity, in contrast, showed a progressive decrease from that of summer monsoon (Appendix Fig. A3). In addition, the low salinity waters also showed a further southward extension. This indicated that the shallow MLD in the northern part of the bay and its further southward extension was linked to the presence of low salinity waters and its southward advection. As seen from the data, the river discharge was dominant from July to October and hence the low salinity of the surface water was the manifestation of the river influence. With the setting in of the fall intermonsoon, the winds over the Bay of Bengal showed a drastic reduction in their speed in the north (Appendix Fig. A6). However, strong winds still persisted in the southern Bay of Bengal. Thus, the deep MLD in the southern Bay of Bengal was driven by a combination of comparatively high wind speed and the presence of high salinity waters (Appendix Fig. A3) both of which destabilized the water column.

\subsection{Winter monsoon}

The winter monsoon, in general, showed comparatively deep MLD ( 30-40 m) all over the Bay of Bengal except in the northern and eastern parts (Fig. 8). The shallow MLD $(\sim 5-$ $15 \mathrm{~m}$ ) in the northern and eastern Bay of Bengal could be understood in the context of the presence of low salinity waters $(<32 \mathrm{psu})$ during November-December (Appendix Fig. A3) and associated strong stratification. As the winter progressed, the $E-P$ showed a net evaporation in most parts of the bay (Appendix Fig. A8) while the region of low salinity waters were confined to the northern part during January-February. The shallow MLD observed near the 

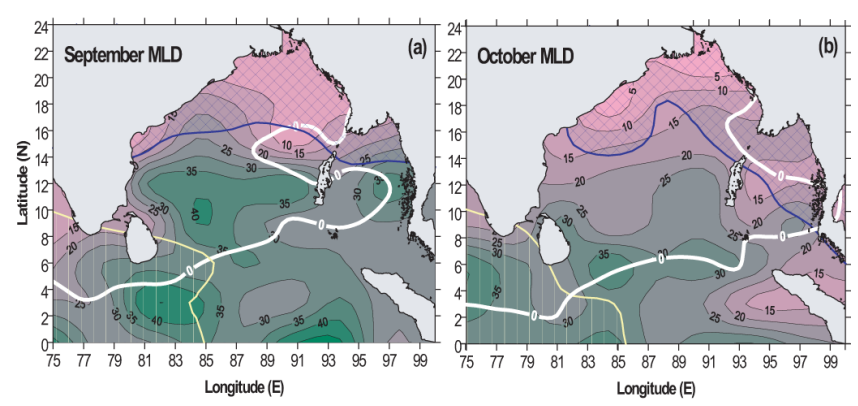

Figure 7. Monthly mean climatology of mixed layer depth (m) in the Bay of Bengal during fall intermonsoon in (a) September and (b) October. The blue crosshatch represents the region where salinity is less than $32 \mathrm{psu}$, while vertical lines within the thin yellow solid line represent the region where the salinity is greater than $34.5 \mathrm{psu}$. The thick broad white line indicates the zero wind stress curl and the region south of it (equatorward) have positive wind stress curl.

Sumatra coast in January was driven by the strengthened positive wind stress curl (Fig. 8c) and the associated upward Ekman pumping. The deep MLD in the rest of the bay was related to the weak stratification that occurred in the bay during winter as could be inferred from the vertical structure of the stability parameter in the upper $40 \mathrm{~m}$ (Fig. 8e). The high wind speeds, which showed a secondary peak in winter (Appendix Fig. A6), were able to initiate deeper wind mixing as the stratification of the water column was at its weakest.

\subsection{Role of Rossby waves}

In order to understand the role of Rossby waves in regulating the MLD, the time-longitude plots of sea-level anomaly overlaid with the mixed layer depth anomaly along two latitudes, 5 and $15^{\circ} \mathrm{N}$ (Fig. 9) were analysed. For this purpose the monthly mean climatology of sea-level anomalies was computed from the monthly mean sea-level anomaly data for the period 1992-2006. MLD anomalies were computed by removing the annual mean from monthly mean climatology.

The salient feature of the time-longitude plot of the sealevel anomaly (SLA) along $5^{\circ} \mathrm{N}$ was the presence of a band of strong positive anomaly sandwiched between two bands of negative anomalies. These alternate bands of positive and negative SLA with sloping contours were the signature of westward propagating Rossby waves (Fig. 9). These waves with a positive SLA during summer and negative SLA during winter had annual periodicity. Note that the MLD anomaly also followed a similar pattern as that of the SLA indicating the signature of Rossby wave propagation. The cooccurrence of the positive MLD anomaly and SLA during June-August indicated the role of Rossby waves in deepening the MLD. In contrast, the time-longitude plot of the SLA along $15^{\circ} \mathrm{N}$ showed an alternate band of positive and negative SLA with sloping contours the positive MLD anomaly did not always co-occur with the positive SLA. Thus, during
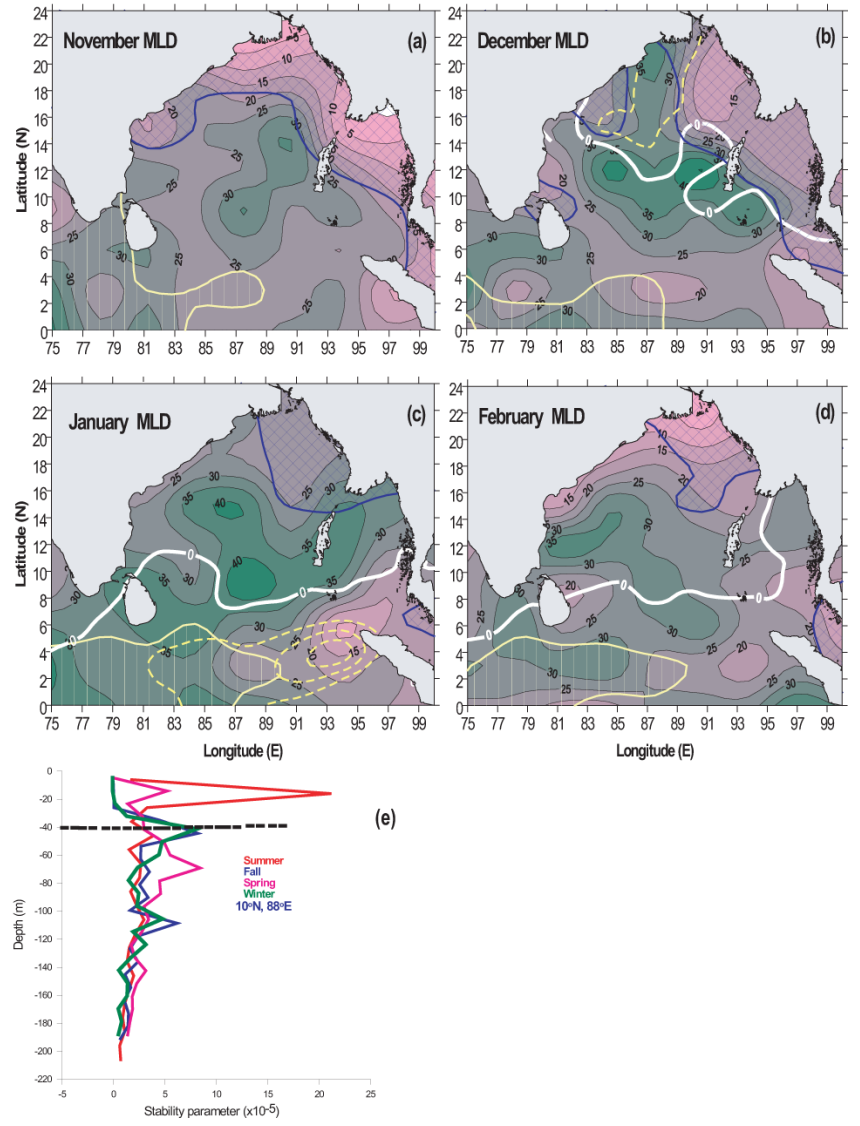

(e)

Figure 8. Monthly mean climatology of mixed layer depth (m) in the Bay of Bengal during winter in (a) November, (b) December, (c) January, and (d) February and (e) vertical profiles of the upper ocean stability parameter $\left(E, \mathrm{~m}^{-1}\right)$ at $10^{\circ} \mathrm{N}, 88^{\circ} \mathrm{E}$. In (a-d) the blue crosshatch represents the region where salinity is less than $32 \mathrm{psu}$, while vertical lines within the thin yellow solid line represent the region where the salinity is greater than $34.5 \mathrm{psu}$. The thick broad white line indicates the zero wind stress curl and the region south of it (equatorward) have positive wind stress curl. The yellow broken contours indicate the positive wind stress curl (5$20 \times 10^{-8} \mathrm{~Pa} \mathrm{~m}^{-1}$ ) with increasing magnitude towards the centre.

summer the deep MLD in the southern BOB (Bay of Bengal) was strongly coupled to the propagation of Rossby waves, while towards the northern BOB its influence was less visible.

A schematic figure depicting various processes that control the mixed layer depth on a seasonal timescale is given in Appendix 9.

\subsection{Nitrate and chlorophyll}

Having examined the seasonal cycle of basin-scale mixed layer variability, it is important to analyse the water-column nitrate and chlorophyll to understand how they respond to the changes in the MLD. Towards this, the nitrate and chlorophyll $a$ at 10, 20, 50, and $100 \mathrm{~m}$ were analysed and presented 

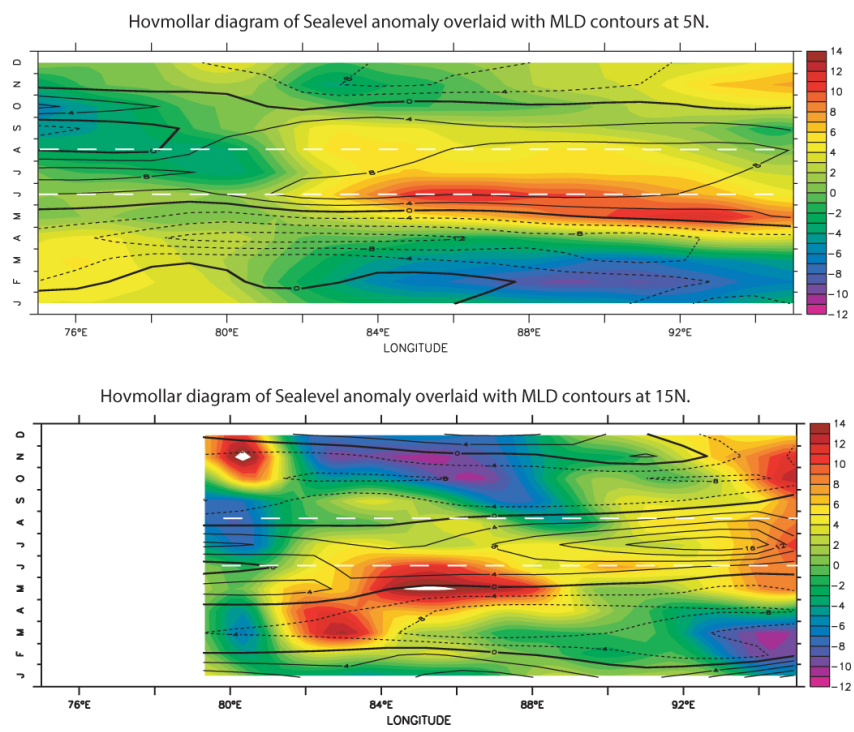

Figure 9. Time-longitude plots of monthly mean sea-level anomaly climatology (1992-2006) derived from merged sea-level anomalies of Topex/Poseidon and ERS $1 / 2$ satellites overlaid with the mixed layer depth anomaly along $5^{\circ} \mathrm{N}$ (top panel) and $15^{\circ} \mathrm{N}$ (bottom panel) latitudes.

below. Surface values are not presented since the nitrate concentrations are generally in the undetectable levels. Only three seasons, namely spring intermonsoon, summer monsoon and winter monsoon, were considered as data in the fall intermonsoon was very sparce, as mentioned in Sect. 2.2. In addition, the satellite-derived chlorophyll pigment concentrations were also analysed during the four seasons to decipher the seasonal cycle.

\subsubsection{Spring intermonsoon}

The nitrate concentrations at $10 \mathrm{~m}$ in most part of the basin during spring intermonsoon were very low $\sim 0.5 \mu \mathrm{M}$ (Fig. 10a). Along the northern and western Bay of Bengal a high concentration was seen with the values in excess of $1 \mu \mathrm{M}$. A large patch in the central Bay of Bengal also showed nitrate concentrations in the range of $1-1.5 \mu \mathrm{M}$. At $20 \mathrm{~m}$, high nitrate concentrations in the range of $1-2 \mu \mathrm{M}$ were seen along the western and northeastern boundaries. The highest concentration of $3 \mu \mathrm{M}$ was noticed north of Sri Lanka as a patch extending eastward (Fig. 10b). Similarly, two more patches of high nitrate concentration were seen south of Sri Lanka and southeastern Bay of Bengal respectively. The distribution pattern at $50 \mathrm{~m}$ depth was similar to that of $20 \mathrm{~m}$, but concentration levels were much higher ranging between 2 and $12 \mu \mathrm{M}$ (Fig. 10c). At $100 \mathrm{~m}$ depth nitrate concentration showed several eddy-like mesoscale variabilities and the values varied between 8 and $24 \mu \mathrm{M}$ (Fig. 10d).

The chlorophyll $a$ concentration at $10 \mathrm{~m}$ during spring intermonsoon was, in general, less than $0.2 \mathrm{mg} \mathrm{m}^{-3}$ except
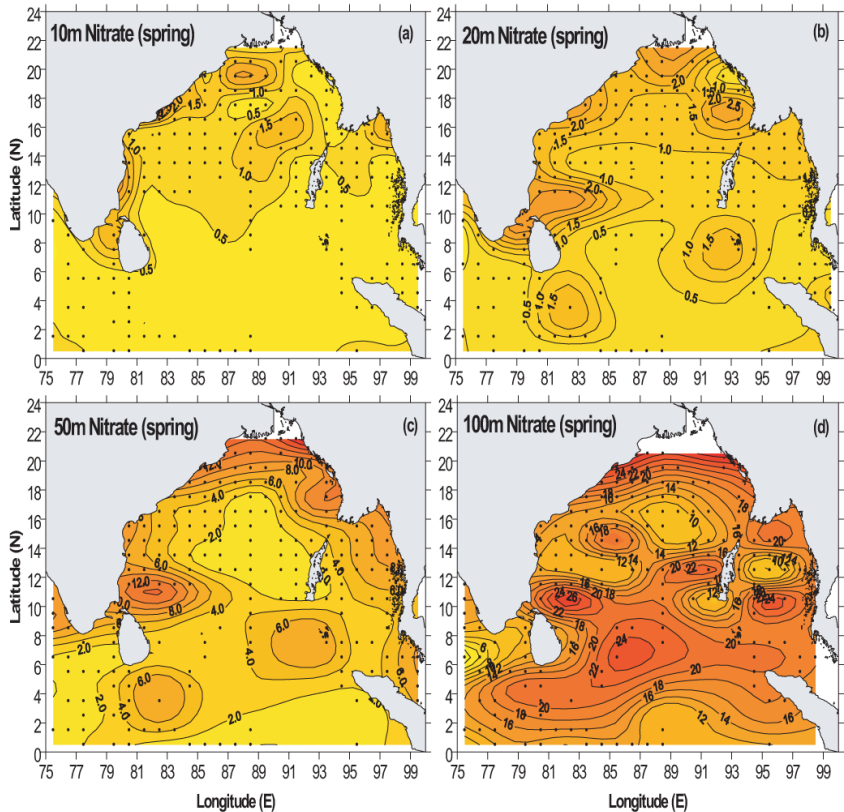

Figure 10. Spatial distribution of nitrate $(\mu \mathrm{M})$ at (a) 10, (b) 20, (c) 50 , and (d) $100 \mathrm{~m}$ during spring intermonsoon. Note the change in contour interval in (c) and (d).

near the southern tip of India and along parts of the western and eastern boundaries (Fig. 11a). The region between $91-98^{\circ} \mathrm{E}$ and $4-10^{\circ} \mathrm{N}$ also showed the highest chlorophyll $a$ concentrations with a maximum value of $0.7 \mathrm{mg} \mathrm{m}^{-3}$. In the central and southern Bay of Bengal chlorophyll $a$ was the lowest and the value varied between 0.1 and $0.2 \mathrm{mg} \mathrm{m}^{-3}$. Though the spatial distribution pattern of chlorophyll $a$ at 20 and $50 \mathrm{~m}$ (Fig. $11 \mathrm{~b}, \mathrm{c}$ ) was similar to that of $10 \mathrm{~m}$, the values showed an increase. The value varied between 0.2 and $1.0 \mathrm{mg} \mathrm{m}^{-3}$. At $100 \mathrm{~m}$ the chlorophyll $a$ concentrations in the entire Bay of Bengal were less than $0.2 \mathrm{mg} \mathrm{m}^{-3}$ except in the southeastern part of the bay where it showed an increase from 0.2 to $0.7 \mathrm{mg} \mathrm{m}^{-3}$ (Fig. 11d). Though there was a close correspondence, in general, between the regions of enhanced chlorophyll and the regions of higher concentrations of nitrate, there were also distinct disagreements. For example, the region northwest of Sumatra showed high chlorophyll $a$ values in the surface, however, a corresponding high level of nitrate was not discernible. Conversely, a distinct high nitrate concentration was seen along the southern part of the western boundary, but no such enhancement was seen in the chlorophyll. This mismatch points to the data inadequacy.

\subsubsection{Summer monsoon}

The salient feature of nitrate distribution in the upper $20 \mathrm{~m}$ during summer was the presence of high concentrations in the Indo-Sri Lankan region where the highest values were $6 \mu \mathrm{M}$ near peninsular India and $3 \mu \mathrm{M}$ off Sri Lanka (Fig. 12a, b). Another region of high concentration was in the northern 


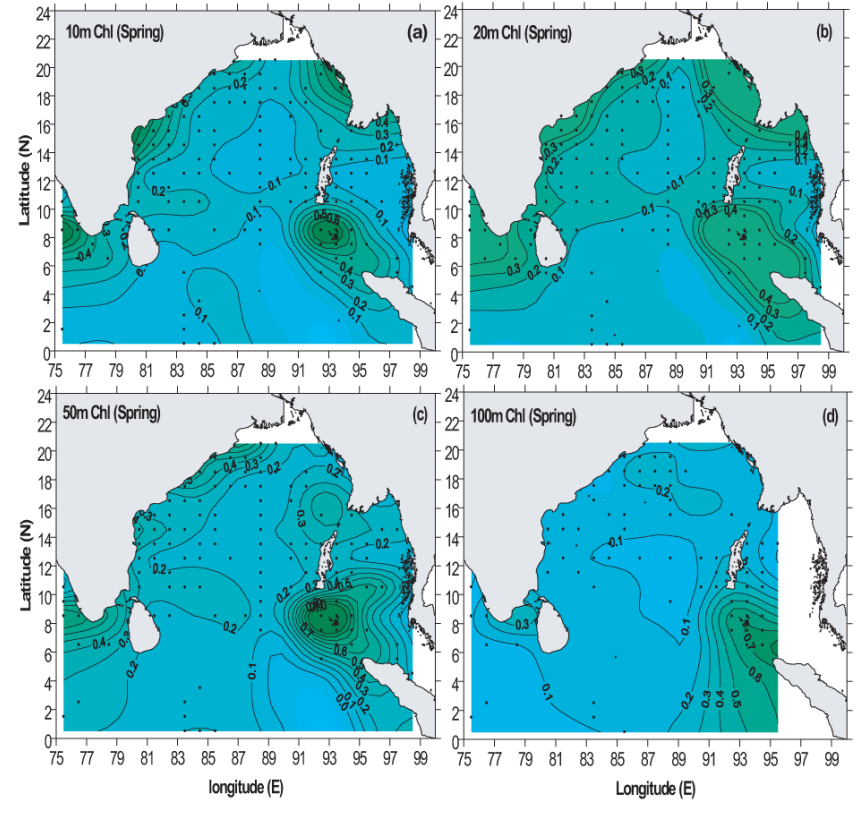

Figure 11. Spatial distribution of chlorophyll $a\left(\mathrm{mg} \mathrm{m}^{-3}\right)$ at (a) 10 , (b) 20, (c) 50, and (d) $100 \mathrm{~m}$ during spring intermonsoon.

Bay of Bengal. The rest of the bay had nitrate concentrations less than $0.5 \mu \mathrm{M}$. At 50 and $100 \mathrm{~m}$, however, the closed contour patterns which were prominently seen should be taken with caution as this could arise due to the efficacy of interpolation of less adequate data (Fig. 12c, d).

The spatial distribution of chlorophyll $a$ at $10 \mathrm{~m}$ showed the highest concentration of $0.5 \mathrm{mg} \mathrm{m}^{-3}$ in the northern Bay of Bengal and also along the western boundary (Fig. 13a). However, the pattern was completely different at $20 \mathrm{~m}$ and the region of highest chlorophyll $a$ with a value of $\sim 2 \mathrm{mg} \mathrm{m}^{-3}$ was seen in the Indo-Sri Lanka region (Fig. 13b). In the rest of the bay the chlorophyll $a$ concentration was less than $0.2 \mathrm{mg} \mathrm{m}^{-3}$. The low chlorophyll $a$ in the northern part of the bay, in spite of the high nitrate concentration, indicates the possible light limitation as the river runoff brings large amounts of suspended load into the northern part of the bay. A similar result was obtained by Prasanna Kumar et al. (2010) using in situ data on chlorophyll $a$ and primary productivity $(\mathrm{PP})$ collected during the summer monsoon of 2001 (6 July-2 August) along the central BOB and its western boundary. They noted that in spite of nitrate concentrations being $1 \mu \mathrm{M}$ in the upper $10 \mathrm{~m}$, the PP was very low in comparison to the southern BOB. They further noted that the chlorophyll $a$ within the subsurface chlorophyll maximum (SCM) during summer in the northern BOB was less than half of that of the spring intermonsoon value. All of the above corroborates the light limitation in the northern BOB. The pattern of high values near the Indo-Sri Lanka region and very low values in the rest of the bay remained the same up to $100 \mathrm{~m}$, though their magnitude showed a progressive
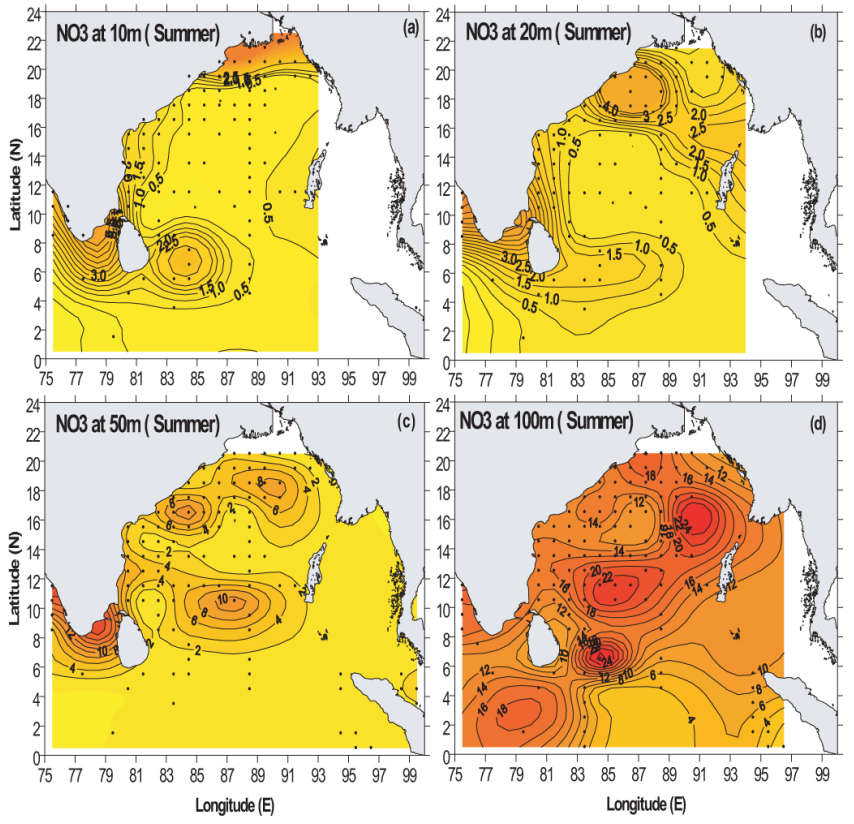

Figure 12. Spatial distribution of nitrate $(\mu \mathrm{M})$ at (a) 10 , (b) 20 , (c) 50 , and (d) $100 \mathrm{~m}$ during summer monsoon. Note the change in contour interval in (c) and (d).

decrease with depth (Fig. 13c, d). Note that in spite of high nitrate concentration at $10 \mathrm{~m}$ depth the chlorophyll $a$ values did not indicate any enhancement.

\subsubsection{Winter monsoon}

The nitrate distribution at 10 and $20 \mathrm{~m}$ (Fig. 14a, b) during the winter season showed very low concentrations in most parts of the bay $(<0.2 \mu \mathrm{M})$, except the region off Sumatra. At 50 and $100 \mathrm{~m}$ the nitrate concentrations varied between 2 and $24 \mu \mathrm{M}$ (Fig. 14c, d). As in summer monsoon, the closedcontour feature was discernible at these depths.

The chlorophyll $a$ distribution in winter at 10 and $20 \mathrm{~m}$ was similar to spring intermonsoon, with high values along the western and eastern parts of the bay, and low values $\left(<0.1 \mathrm{mg} \mathrm{m}^{-3}\right)$ in the rest of the bay (Fig. 15a, b). At $50 \mathrm{~m}$ the chlorophyll $a$ over the bay varied between 0.1 and $0.3 \mathrm{mg} \mathrm{m}^{-3}$ except along the western boundary where it was more than $0.4 \mathrm{mg} \mathrm{m}^{-3}$ (Fig. 15c). At $100 \mathrm{~m}$, most of the Bay of Bengal showed low chlorophyll $a$ with concentrations of about $0.1 \mathrm{mg} \mathrm{m}^{-3}$, except a patch near the southwestern part of the bay where the concentration was $\sim 0.5 \mathrm{mg} \mathrm{m}^{-3}$ (Fig. 15d). As in the case of spring intermonsoon, we see a mismatch between nitrate concentration and chlorophyll biomass in the Sumatra region and in the southern part of the western boundary of BOB underscoring the data inadequacy. 


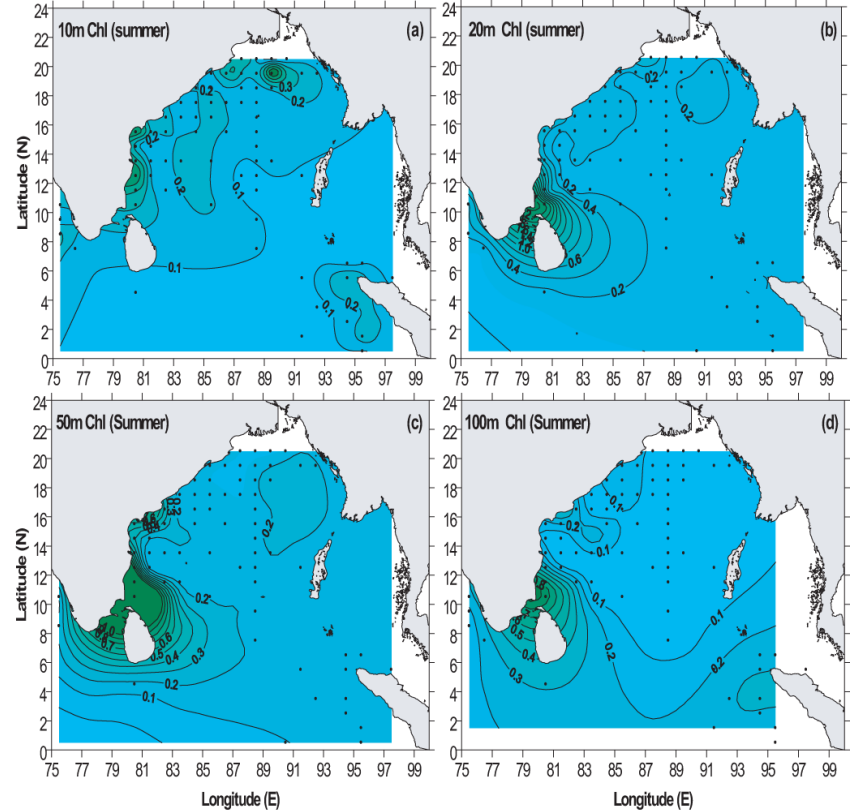

Figure 13. Spatial distribution of chlorophyll $a\left(\mathrm{mg} \mathrm{m}^{-3}\right)$ at (a) 10 , (b) 20, (c) 50, and (d) $100 \mathrm{~m}$ during summer monsoon. Note the change in contour interval in (b).

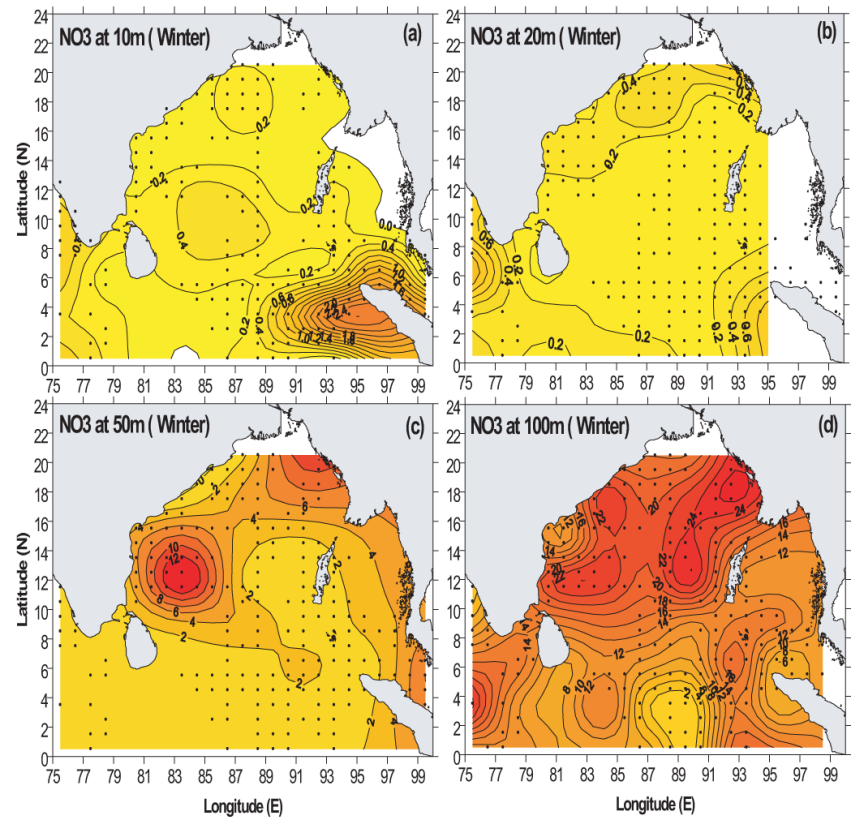

Figure 14. Spatial distribution of nitrate $(\mu \mathrm{M})$ at (a) 10, (b) 20, (c) 50, and (d) $100 \mathrm{~m}$ during winter monsoon. Note the change in contour interval in (c) and (d).

\subsection{Satellite-derived chlorophyll pigment concentrations}

The satellite-derived chlorophyll pigment concentrations showed the lowest value during spring intermonsoon com-
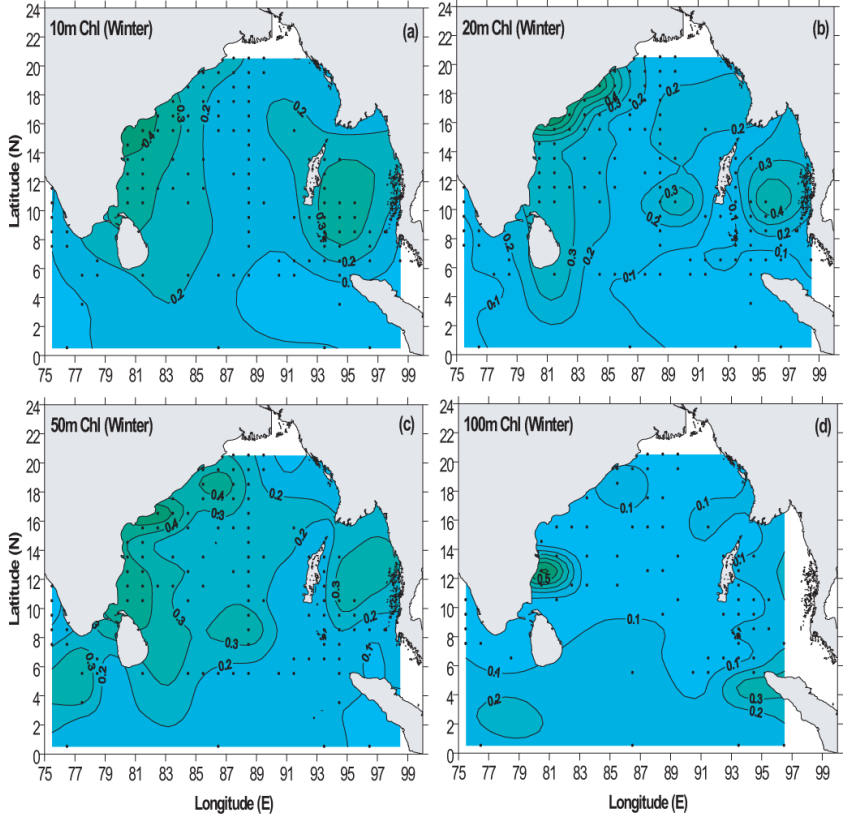

Figure 15. Spatial distribution of chlorophyll $a\left(\mathrm{mg} \mathrm{m}^{-3}\right)$ at (a) 10 , (b) 20, (c) 50, and (d) $100 \mathrm{~m}$ during winter monsoon.

pared to the rest of the three seasons (Fig. 16). The pigment concentrations varied over a very narrow range of $0.1-$ $0.2 \mathrm{mg} \mathrm{m}^{-3}$, except at the head of the Bay of Bengal and close to peninsular India and Sri Lanka where it marginally increased to $0.3 \mathrm{mg} \mathrm{m}^{-3}$ (Fig. 16a). The chlorophyll pigment concentrations during summer monsoon were the highest followed by the fall intermonsoon (Fig. 16b, c). The region of highest chlorophyll pigment concentration was located in a region encompassing peninsular India, Sri Lanka and northern part of the bay. These patterns were comparable with the in situ concentrations seen in the earlier section. The northern Bay of Bengal showed a maximum value of about $1 \mathrm{mg} \mathrm{m}^{-3}$, while near the Indo-Sri Lanka region it varied between 0.5 and $10 \mathrm{mg} \mathrm{m}^{-3}$. Note that the red band, usually seen very close to the coast in the pigment concentration map, is largely due to sediments and should be neglected. During winter the chlorophyll pigment concentration showed a further reduction from that of the fall intermonsoon with the values ranging between 0.1 and $0.3 \mathrm{mg} \mathrm{m}^{-3}$ in most parts of the bay (Fig. 16d). However, close to the western and eastern boundaries the values varied between 0.3 and $2.5 \mathrm{mg} \mathrm{m}^{-3}$.

\subsection{Partial correlation}

In order to decipher the coupling of chlorophyll with physical parameters, we have examined the partial correlation among MLD, chlorophyll $a(\mathrm{Chl})$, nitrate $\left(\mathrm{NO}_{3}\right)$, SST, WS, NHF, and $E$ - $P$, which is presented in Table 2. The highest correlation of chlorophyll was with nitrate $(0.9)$ followed by wind speed (0.6). Nitrate being the limiting macro-nutrient, the 
Table 2. Partial correlation among MLD, SST, chlorophyll $a(\mathrm{Chl})$, nitrate $\left(\mathrm{NO}_{3}\right), \mathrm{WS}, \mathrm{NHF}$, and $E-P$. Values greater than 0.5 are in boldface.

\begin{tabular}{lrrrrrrr}
\hline $\begin{array}{l}\text { Partial } \\
\text { correlation }\end{array}$ & MLD & Chl & $\mathrm{NO}_{3}$ & SST & WS & NHF & $E-P$ \\
\hline MLD & $\mathbf{- 1 . 0}$ & -0.5 & 0.5 & $\mathbf{- 0 . 8}$ & $\mathbf{0 . 7}$ & 0.1 & $\mathbf{- 0 . 6}$ \\
CHL & -0.5 & $\mathbf{- 1 . 0}$ & $\mathbf{0 . 9}$ & -0.5 & $\mathbf{0 . 6}$ & 0.5 & -0.1 \\
$\mathrm{NO}_{3}$ & 0.5 & $\mathbf{0 . 9}$ & $\mathbf{- 1 . 0}$ & 0.4 & -0.4 & -0.3 & 0.1 \\
SST & $\mathbf{- 0 . 8}$ & -0.5 & 0.4 & $\mathbf{- 1 . 0}$ & $\mathbf{0 . 7}$ & 0.4 & $\mathbf{- 0 . 8}$ \\
WS & $\mathbf{0 . 7}$ & $\mathbf{0 . 6}$ & -0.4 & $\mathbf{0 . 7}$ & $\mathbf{- 1 . 0}$ & -0.5 & 0.4 \\
NHF & 0.1 & 0.5 & -0.3 & 0.4 & -0.5 & $\mathbf{- 1 . 0}$ & -0.1 \\
$E-P$ & $\mathbf{- 0 . 6}$ & -0.1 & 0.1 & $\mathbf{- 0 . 8}$ & 0.4 & -0.1 & $\mathbf{- 1 . 0}$ \\
\hline
\end{tabular}
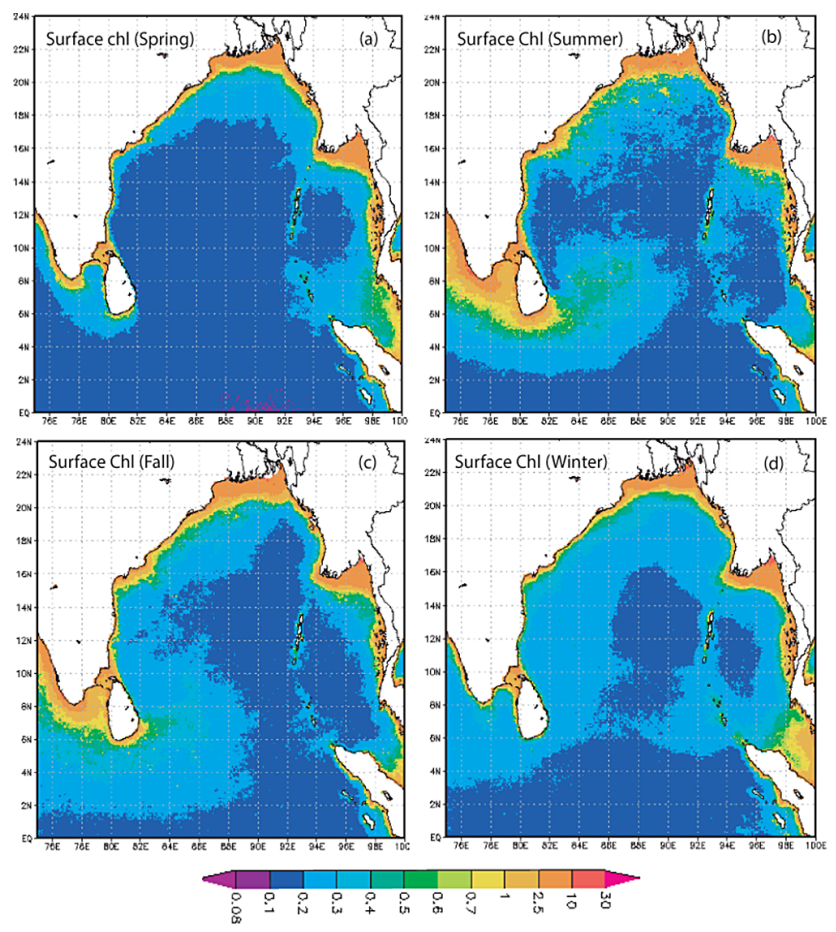

Figure 16. Satellite-derived surface chlorophyll pigment concentrations $\left(\mathrm{mg} \mathrm{m}^{-3}\right)$ in the Bay of Bengal during (a) spring intermonsoon, (b) summer, (c) fall intermonsoon and (d) winter monsoon.

phytoplankton production in the tropical ocean is strongly linked to the availability of this resource. In the BOB nitracline depth is shallow, which is situated just below the mixed layer. Hence, a wind capable of initiating comparatively deep mixing can make the nutrients available to the euphotic zone and support an enhanced primary production. Interestingly, MLD showed only a weak correlation with chlorophyll. This needs to be examined in the light of factors controlling the mixed layer in the BOB. The partial correlation showed that MLD is strongly coupled to SST, wind speed and $E-P$ in that order. Since MLD is expected to decrease with increased Ekman pumping, as in the case near the Indo-Sri Lanka region during summer monsoon, the SST should decrease and hence the observed high but negative correlation. Similarly, an increased precipitation would lead to a decrease in the MLD resulting in the observed negative correlation with $E$ $P$. The weak correlation of chlorophyll either with MLD or with SST implies that under the influence of excess precipitation over evaporation and river discharge, as happens during summer monsoon, the shallow mixed layer will not lead to nutrient supply through entrainment processes to the euphotic zone to sustain high chlorophyll biomass.

\section{Summary and discussion}

The most notable feature of the present study is that it collates available in situ temperature and salinity data in the Bay of Bengal from a variety of sources such as hydrocast, CTD and Argo to examine the basin-wide variability of the mixed layer on a seasonal timescale. It further examined the less explored coupling between mixed layer variability and changes in the chlorophyll biomass in the Bay of Bengal by assembling all the available in situ chlorophyll and nutrient data. Most of the earlier studies attempted to understand mixed layer variability in the tropical Indian Ocean, of which the Bay of Bengal forms a part, either using monthly mean climatology (e.g. Rao et al., 1989; Monterery and Levitus, 1997) or using individual cruise-based data of limited spatial and temporal coverage (e.g. Gopalakrishna et al., 1988; Prasad, 2004; Narvekar and Prasanna Kumar, 2006). A major conclusion of these studies was that wind-driven mixing and net heat flux largely controlled the seasonal cycle of mixed layer depth in the open Bay of Bengal (see Kirthi et al., 2012, and the references therein), while fresh water flux driven stratification was important in the northern Bay of Bengal during summer monsoon (Han et al., 2001; Shenoi et al., 2002; Anitha et al., 2008; Seo et al., 2009). The present study explored the role of Rossby wave propagation and advection of high salinity Arabian Sea waters in regulating the basin-wide mixed layer depth, in addition to the fluxes of heat and fresh water.

The characteristic feature of the variability of basin-wide mixed layer depth in the Bay of Bengal was (1) a distinct 
seasonality and (2) a striking north-south variability in any given season. This indicated the role of a temporally varying ocean-atmospheric process in regulating the mixed layer depth and also the impact of spatially different processes controlling the mixed layer in any given season. These spatially and temporally varying processes controlling the mixed layer, in turn, could potentially influence the availability of nutrients in the upper ocean (euphotic zone) thereby modulating the chlorophyll biomass through photosynthetic processes. During the spring intermonsoon, peak solar heating and associated net heat flux maxima strongly stratify the upper ocean waters. The prevailing weak and variable winds are unable to initiate deep mixing due to the strong stratification, leading to the formation of a shallow mixed layer. The presence of a comparatively shallower MLD in the northern Bay of Bengal compared to the southern part indicates the role of low salinity waters in augmenting the stratification in the north. A combination of processes such as strong thermal stratification and weak winds could explain the presence of a basin-wide shallow MLD during spring intermonsoon, while the latitudinal gradient in upper ocean salinity offers an explanation for the spatial variation of the MLD through haline stratification. Consistent with this, the basin-wide nitrate concentration as well as chlorophyll biomass in the upper water column, away from coastal boundary, was very low. The satellite-derived chlorophyll pigment concentration also showed a similar pattern with low values. Caution must be exercised in drawing inferences on the small-scale features seen in both nitrate and chlorophyll contours which are not spatially collocated. This could be due to the artifact of contouring in regions which are undersampled. Thus, the basinscale nitrate concentration and chlorophyll biomass indicated the prevalence of oligotrophic conditions during spring intermonsoon associated with the shallow mixed layer arising from a combination of strong thermohaline stratification and weak winds.

In summer, when basin-wide winds were the strongest, a corresponding deep mixed layer was not seen in the entire basin. Instead a strong spatial gradient with very shallow mixed layer in the north and deep mixed layer towards south was observed, except in the region off the southern part of peninsular India and off the eastern part of Sri Lanka. Though this pattern of spatial distribution was similar to that of the spring intermonsoon, except in the region off peninsular India and Sri Lanka, the latitudinal gradient was much stronger especially towards the north. The shallow mixed layer in the northern Bay of Bengal was the combined effect of excess precipitation over evaporation and the freshwater influx from the adjoining rivers, both of which result in producing strong haline stratification. However, the winds, though strong in the northern Bay of Bengal, were unable to break the stratification and initiate deep wind mixing as inferred from the static stability parameter. A similar result was arrived at by Shenoi et al. (2002) based on kinetic energy and by Vinayachandran et al. (2002) in the context of barrier layer forma- tion (see also Thadathil et al., 2007). Using modelling, Han et al. (2001) also obtained a thin mixed layer in the region where precipitation exceeded evaporation.

The deep mixed layer in the south, however, was driven by two processes, the advection of high salinity waters from the Arabian Sea into the Bay of Bengal and the westward propagation of Rossby waves from the eastern boundary. Narvekar and Prasanna Kumar (2006) obtained a similar conclusion while examining the MLD variability in the central Bay of Bengal during summer monsoon. In the present study the band of deep MLD extending from the southwestern Bay of Bengal into the central part of the bay was associated with the advection of Arabian Sea high salinity waters, while the deep MLD in the central and eastern parts of the bay was associated with the propagation of Rossby wave of annual periodicity. The shallow mixed layer seen off the southern part of peninsular India was due to the monsoon-driven upwelling, while that east of Sri Lanka was due to the upward Ekman pumping and associated Sri Lanka dome (Vinayachandran and Yamagata, 1998).

The basin-wide nitrate distribution showed two distinct regions of elevated concentrations, one in the northern Bay of Bengal and the other a region encompassing the southern part of peninsular India and the region east of Sri Lanka. The chlorophyll $a$ biomass in the northern Bay of Bengal though showed a weak increase in the surface, it was not commensurate with the nutrient availability in the upper $50 \mathrm{~m}$. Based on in situ measurements of chlorophyll and nutrients and the satellite-derived diffuse attenuation coefficient and photosynthetically active radiation (PAR), Prasanna Kumar et al. (2010) showed that though the river influx enhanced the nutrient in the euphotic zone during summer, the associated sediment load severely curtailed the downward penetration of PAR in the northern Bay of Bengal. In the south the chlorophyll $a$ biomass showed a strong enhancement in accordance with the nitrate concentration in the Indo-Sri Lanka region which was driven by the upwelling along the southern part of peninsular India and upward Ekman pumping east of Sri Lanka (Vinayachandran, 2013).

During the fall intermonsoon, the spatial distribution of mixed layer depth was similar to that of summer monsoon except that the shallow MLD in the Indo-Sri Lanka region weakens and disappears with the weakening of summer monsoon winds. Though the in situ nutrient and chlorophyll data were not available for fall intermonsoon, the satellite-derived chlorophyll pigment concentrations showed a pattern similar to that of summer monsoon, except that its intensity was reduced considerably.

In winter the radiated heat loss and evaporative cooling leads to the net heat loss from the upper ocean. The positive fresh water flux $(E-P)$ results in the increase of the surface salinity in winter. The combined effects of net cooling and increase in salinity of the upper water column lead to a rapid basin-wide decrease in water column stratification. This coupled with strong winds leads to greater wind mixing and 
finally the deep mixed layer. The basin-wide nitrate distribution somehow did not manifest the impact of deep mixing by way of nutrient enhancement. Similarly, the distribution of chlorophyll $a$ biomass also did not show any prominent enhancement, except along the southern part of the western boundary. Note that Levy et al. (2007) also identified the western and northeastern Bay of Bengal as the regions of winter bloom based on a novel method using two parameters such as timing of the bloom onset and cumulative increase in chlorophyll. A similar increase was also noticed by Vinayachandran and Mathew (2003) and Vinayachandran (2013) using chlorophyll $a$ climatology from SeaWiFS from 1999 to 2006. Currie et al. (2013) reported not only an increase in surface chlorophyll but also of net primary production in the southern Bay of Bengal during winter. We believe that the reason why the present study could not capture the winter chlorophyll enhancement may be due to the sparse distribution of the available in situ chlorophyll and nitrate data. The partial correlation brings out the strong coupling of chlorophyll with $\mathrm{NO}_{3}$ and wind speed and less strong coupling with the mixed layer, which is consistent with the regional ocean dynamics in the BOB.

\section{Concluding remarks}

The most notable limitation of the study is lack of adequate spatial and temporal coverage of the in situ chlorophyll and nutrient data, unlike the temperature and salinity data. This inhibited us from making a detailed inference on the seasonal cycle of these parameters from monthly mean climatology; instead we have to depend on the seasonal climatology of nitrate and chlorophyll to infer the seasonal cycle. We were also unable to resolve the variability associated with mesoscale eddies which are a dominant mode of intraseasonal variability. The general lack of correspondence between nitrate distribution and chlorophyll biomass points to the efficacy of the sparse data and undersampling in the Bay of Bengal. Though Argo could enrich the temperature and salinity database in the Bay of Bengal, chlorophyll and nutrients data will still have to largely depend on in situ measurements. Hence, to circumvent the inadequacy in the biogeochemical data, a major observational programme needs to be launched in the Bay of Bengal. 


\section{Appendix A}

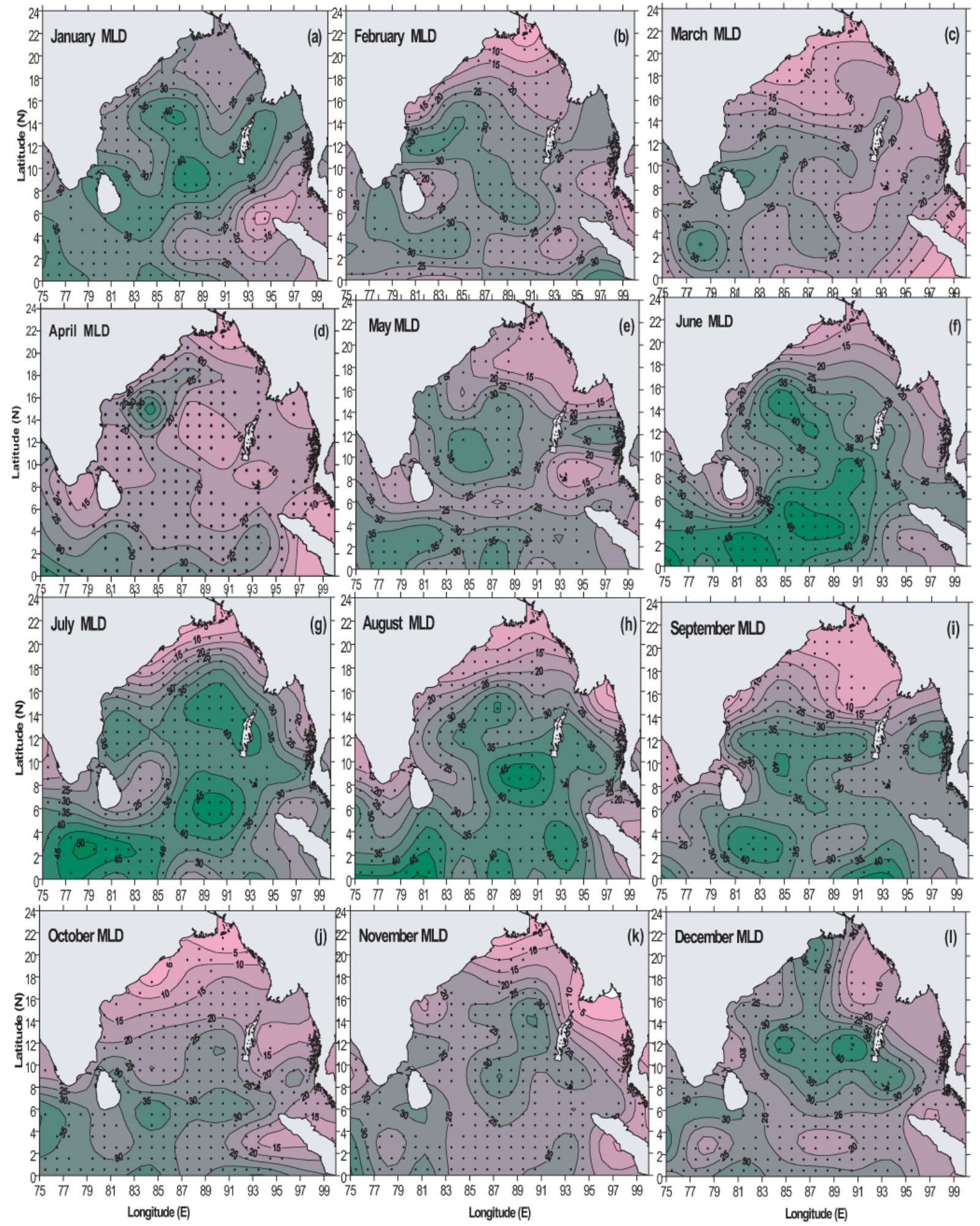

Figure A1. Monthly mean climatology of the mixed layer depth (MLD, m) from January to December. 


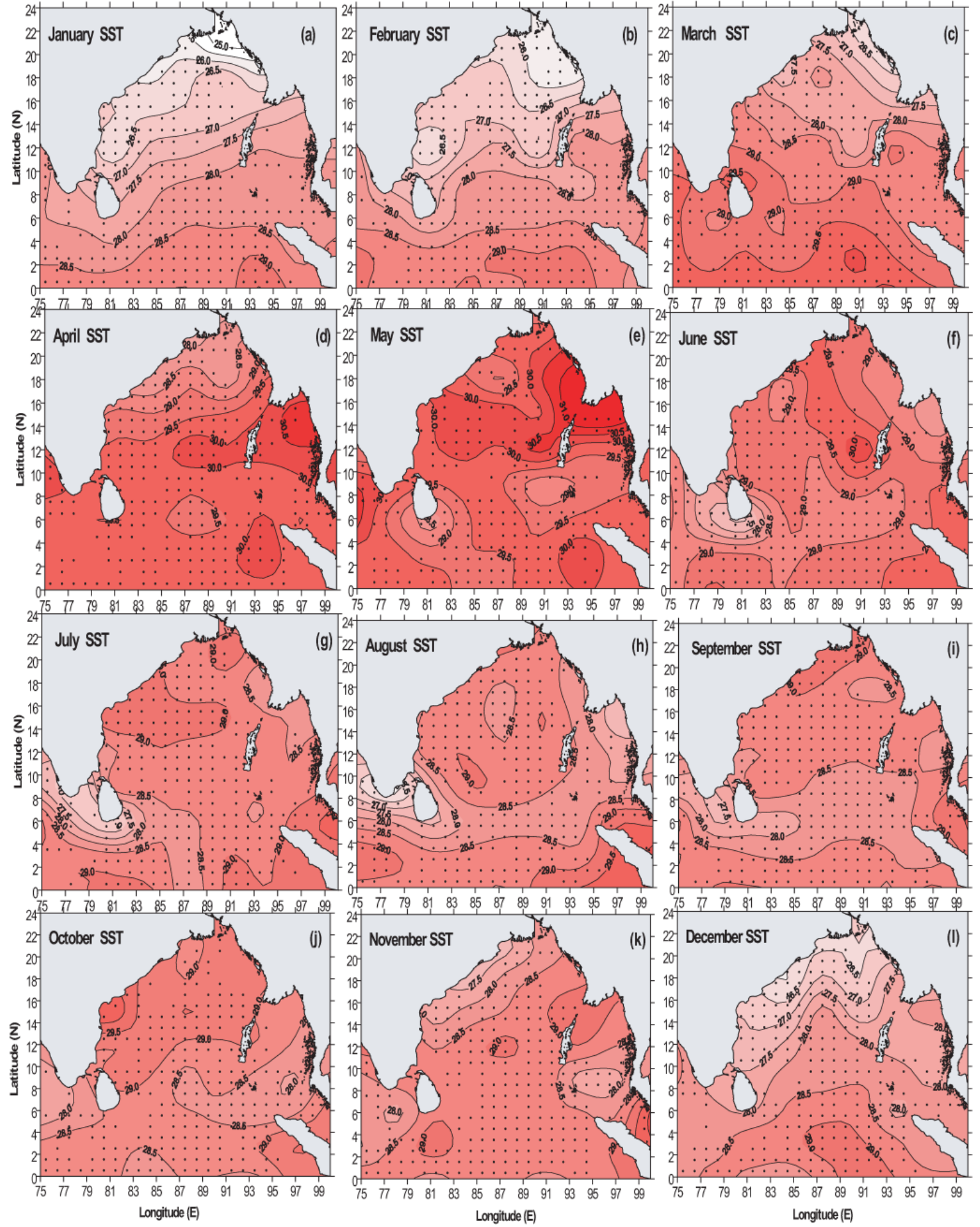

Figure A2. Monthly mean climatology of sea surface temperature (SST, ${ }^{\circ} \mathrm{C}$ ) from January to December. 

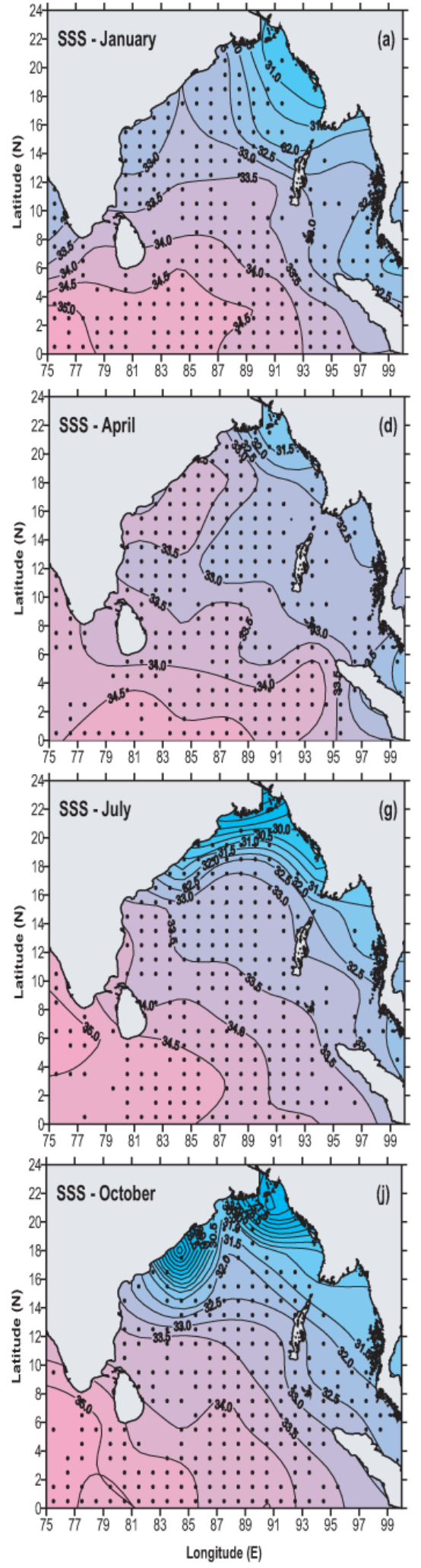
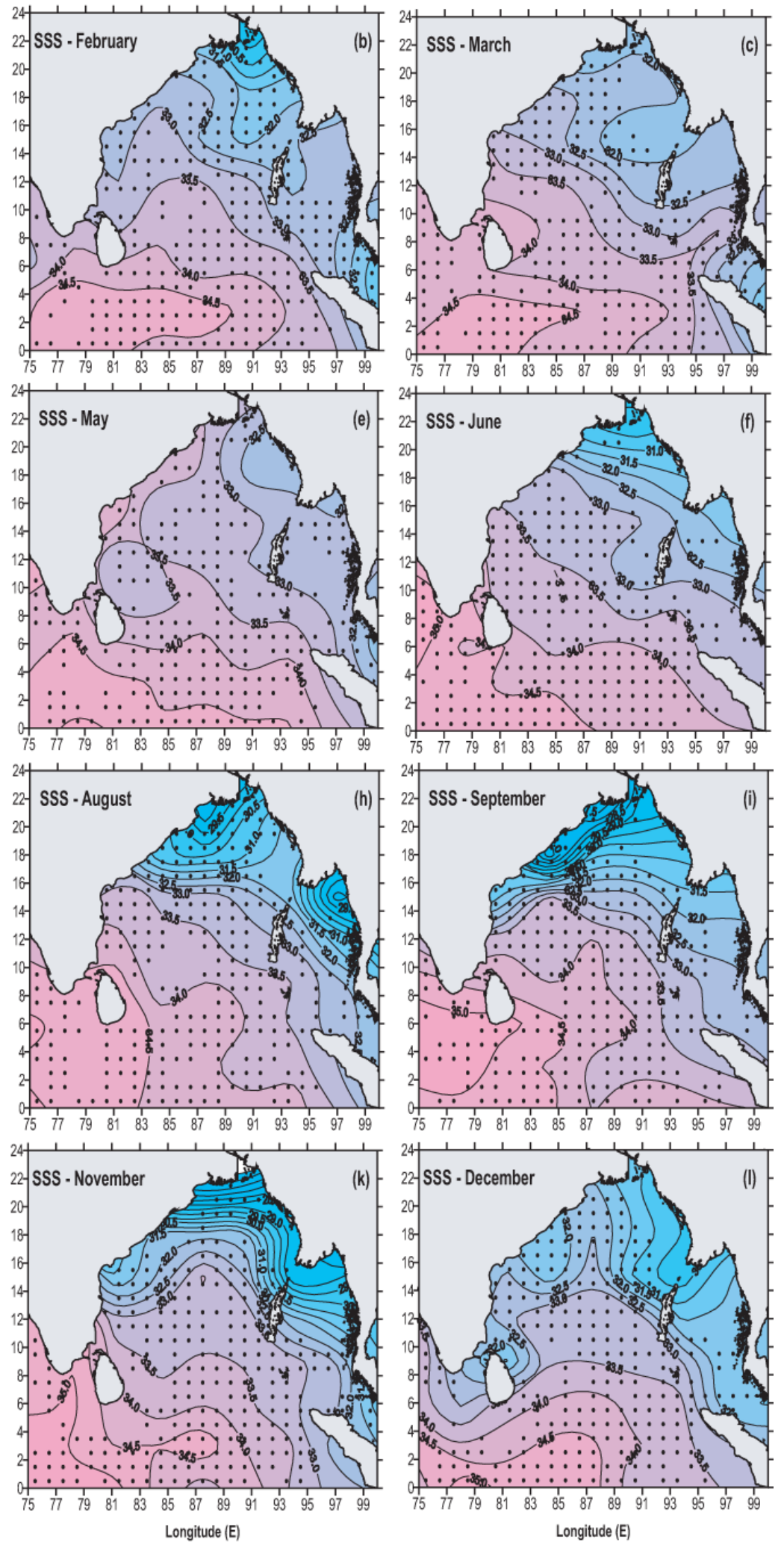

Figure A3. Monthly mean climatology of sea surface salinity (SSS, psu) from January to December. 


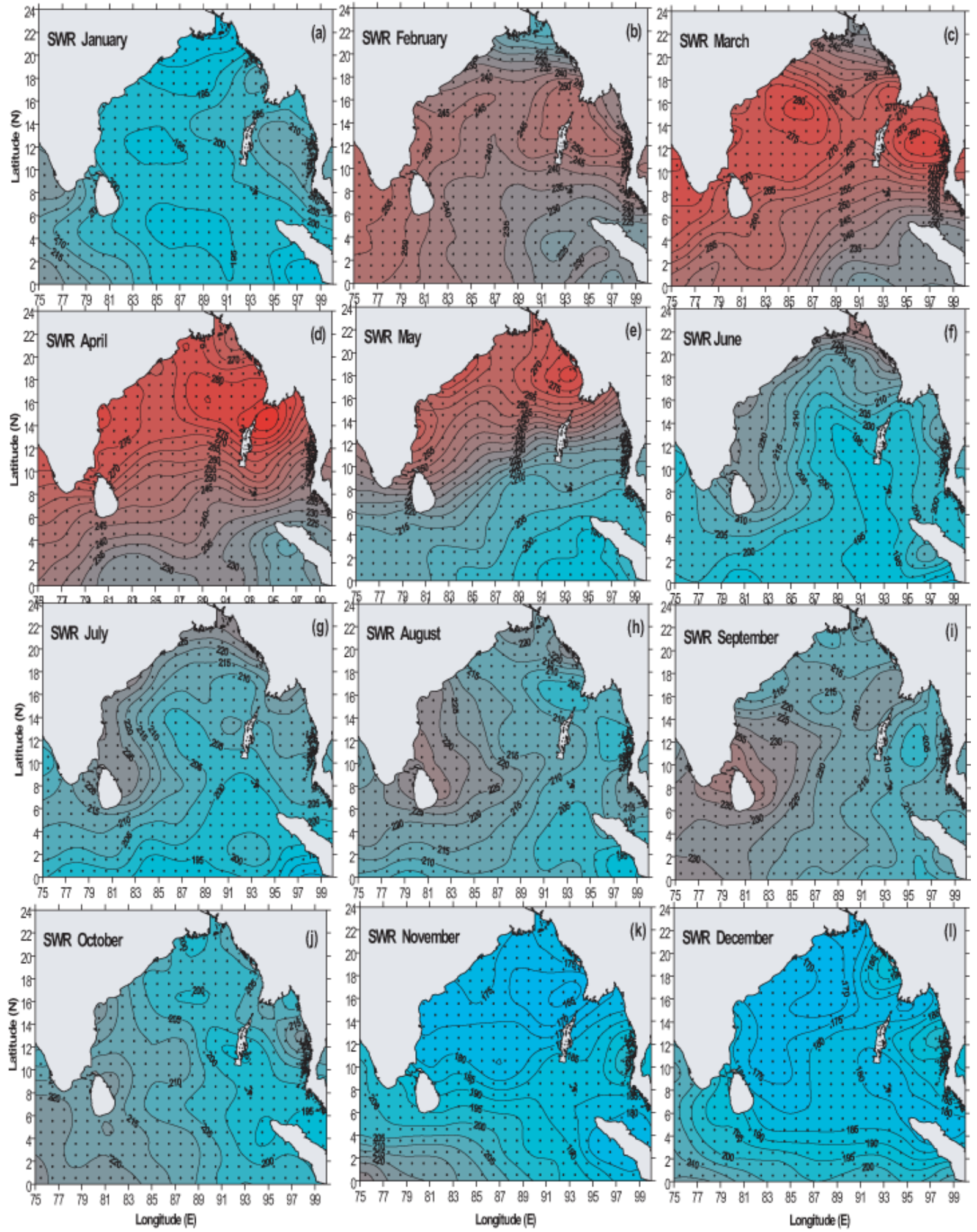

Figure A4. Monthly mean climatology of incoming short wave radiation (SWR, $\mathrm{W} \mathrm{m}^{-2}$ ) from January to December. 

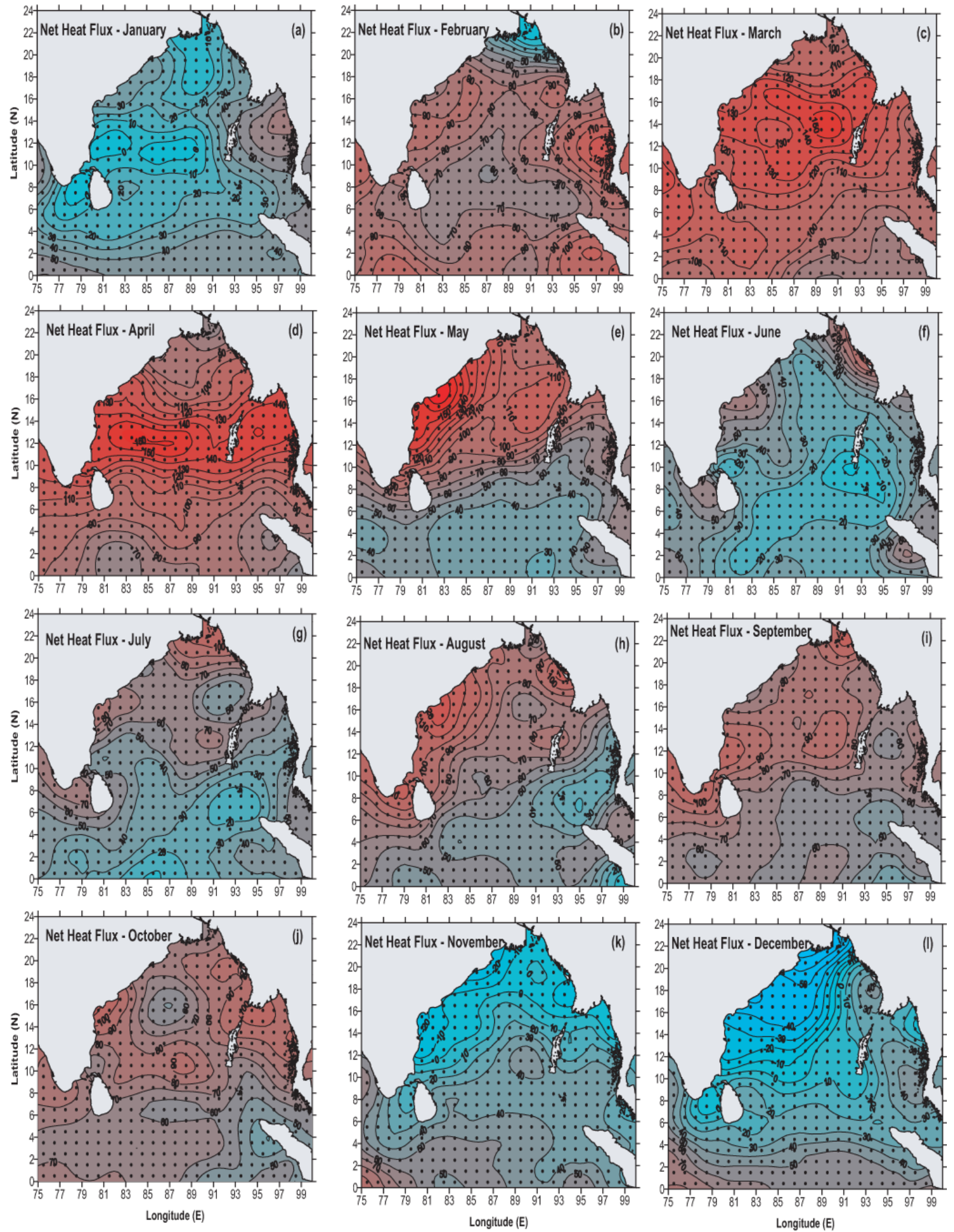

Figure A5. Monthly mean climatology of net heat flux $\left(\mathrm{NHF}, \mathrm{W} \mathrm{m}^{-2}\right.$ ) from January to December. 

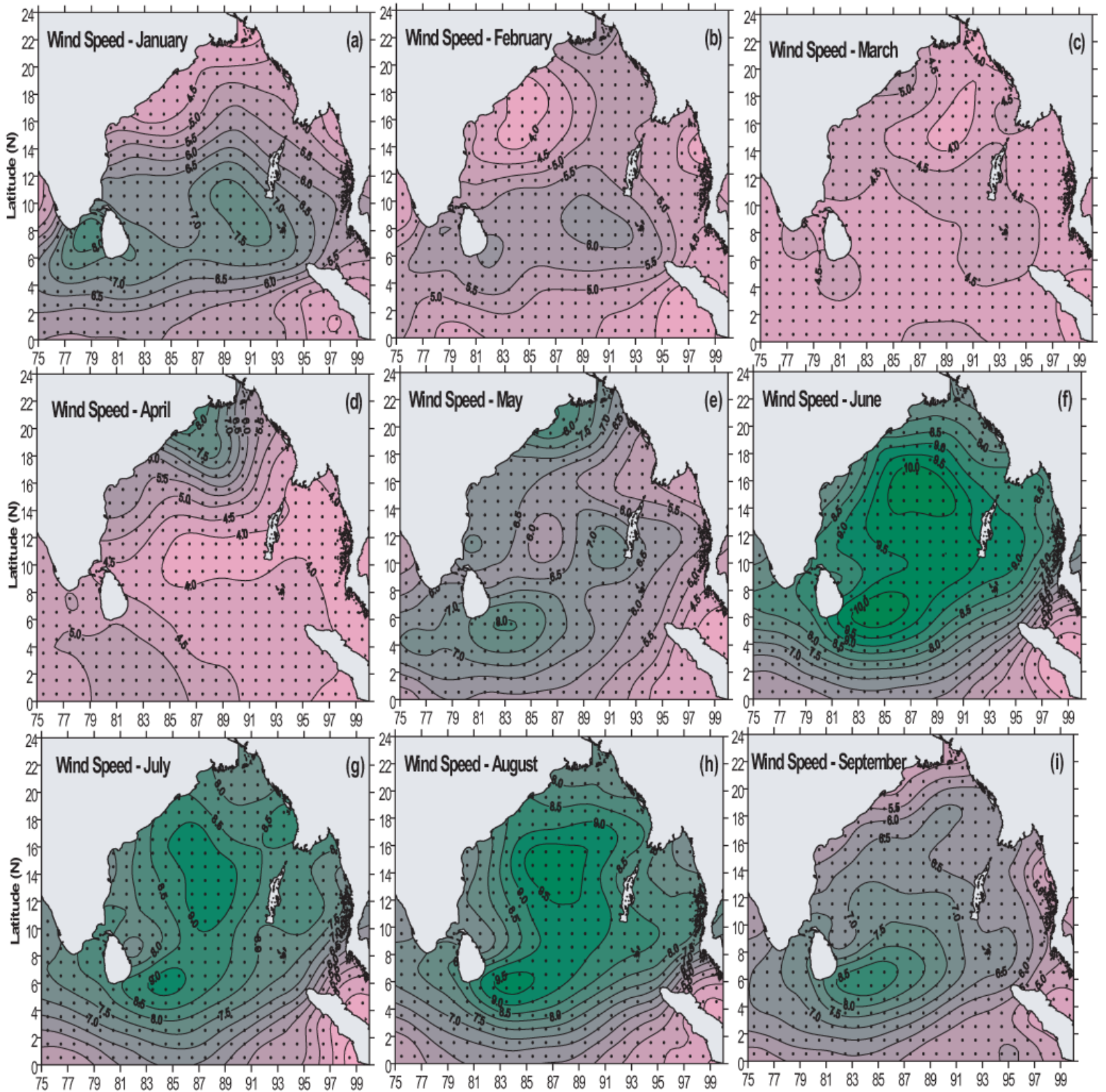

$\begin{array}{lllllllllllll}75 & 77 & 79 & 81 & 83 & 85 & 87 & 89 & 91 & 93 & 95 & 97 & 99\end{array}$

$\begin{array}{llllllllllllll}75 & 77 & 79 & 81 & 83 & 8 & 8 & 87 & 89 & 91 & 93 & 95 & 97 & 99\end{array}$
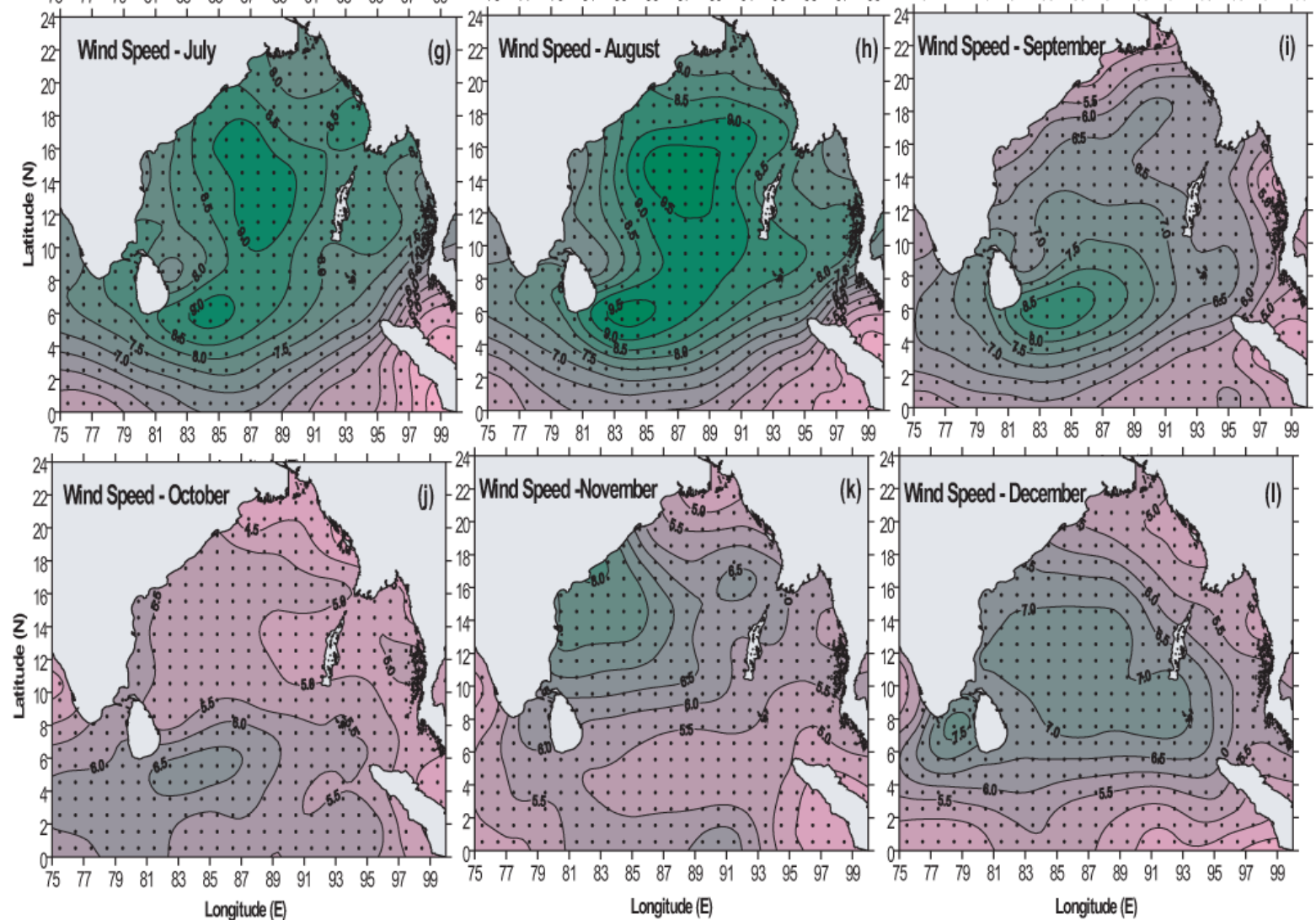

Figure A6. Monthly mean climatology of wind speed (WS, $\mathrm{m} \mathrm{s}^{-1}$ ) from January to December. 

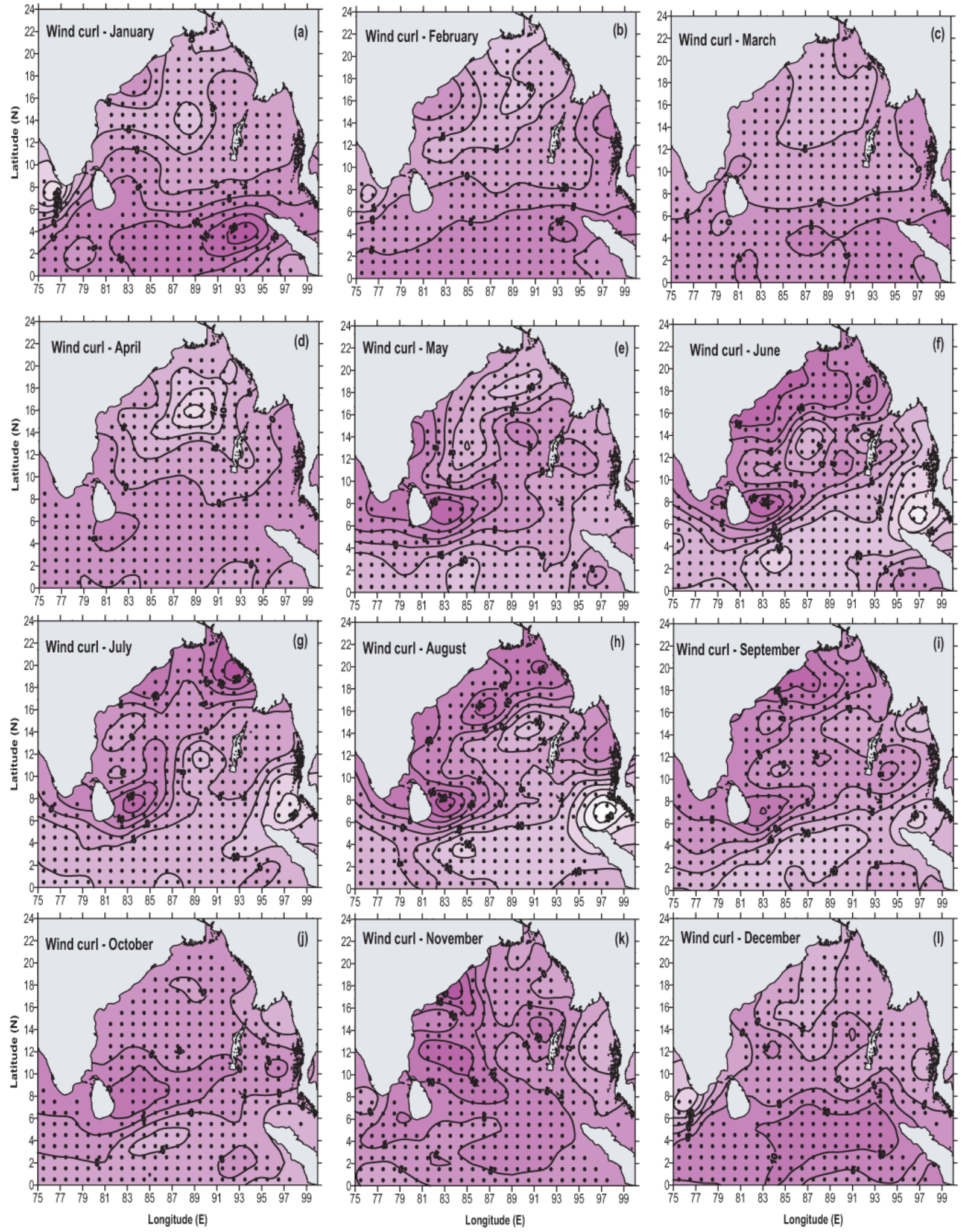

Figure A7. Monthly mean climatology of wind-stress curl $\left(\times 10^{-8} \mathrm{~Pa} \mathrm{~m}^{-1}\right)$ from January to December. 

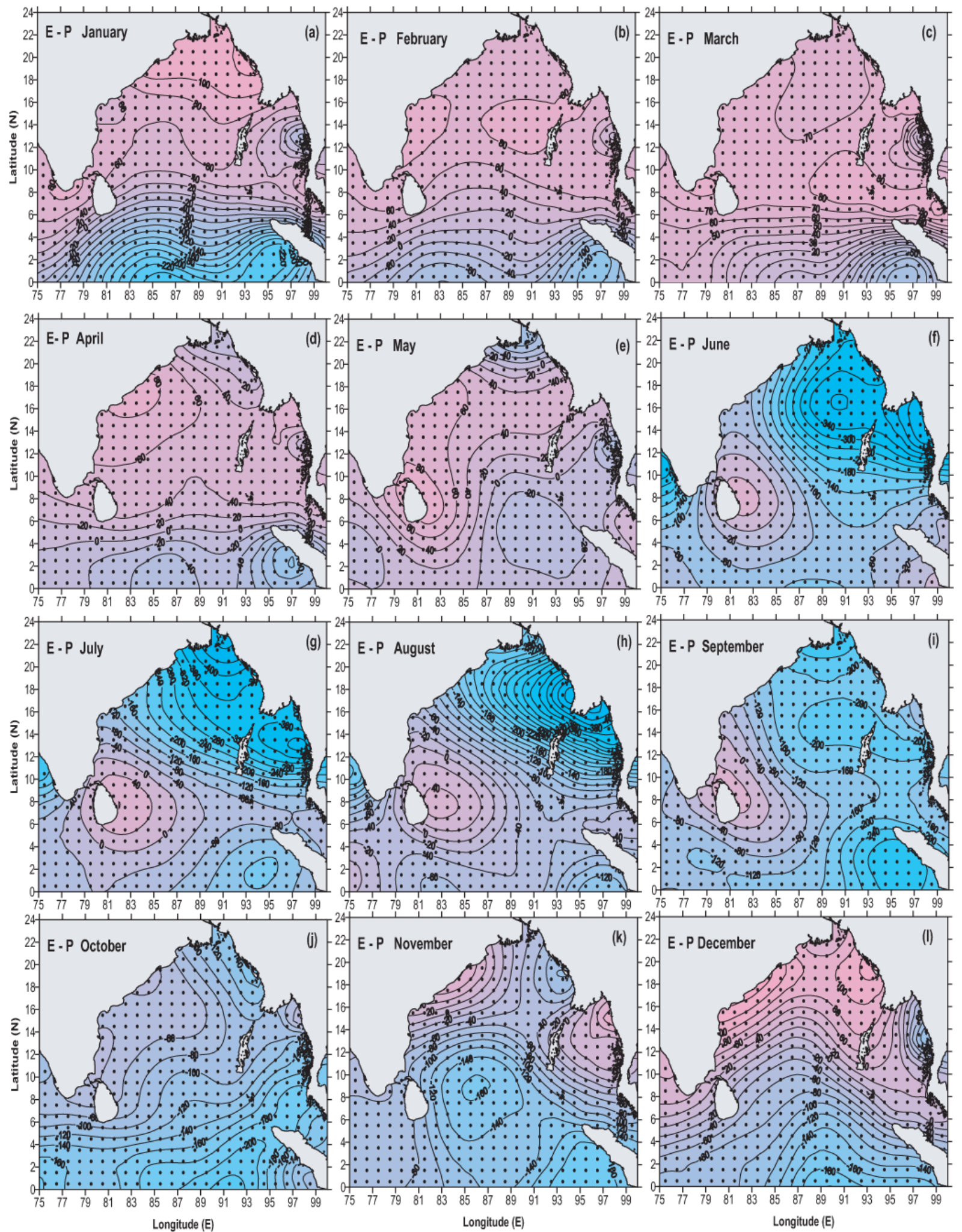

Figure A8. Monthly mean climatology of fresh water flux (evaporation-precipitation) $\left(E-P\right.$, mm month $\left.^{-1}\right)$ from January to December. 


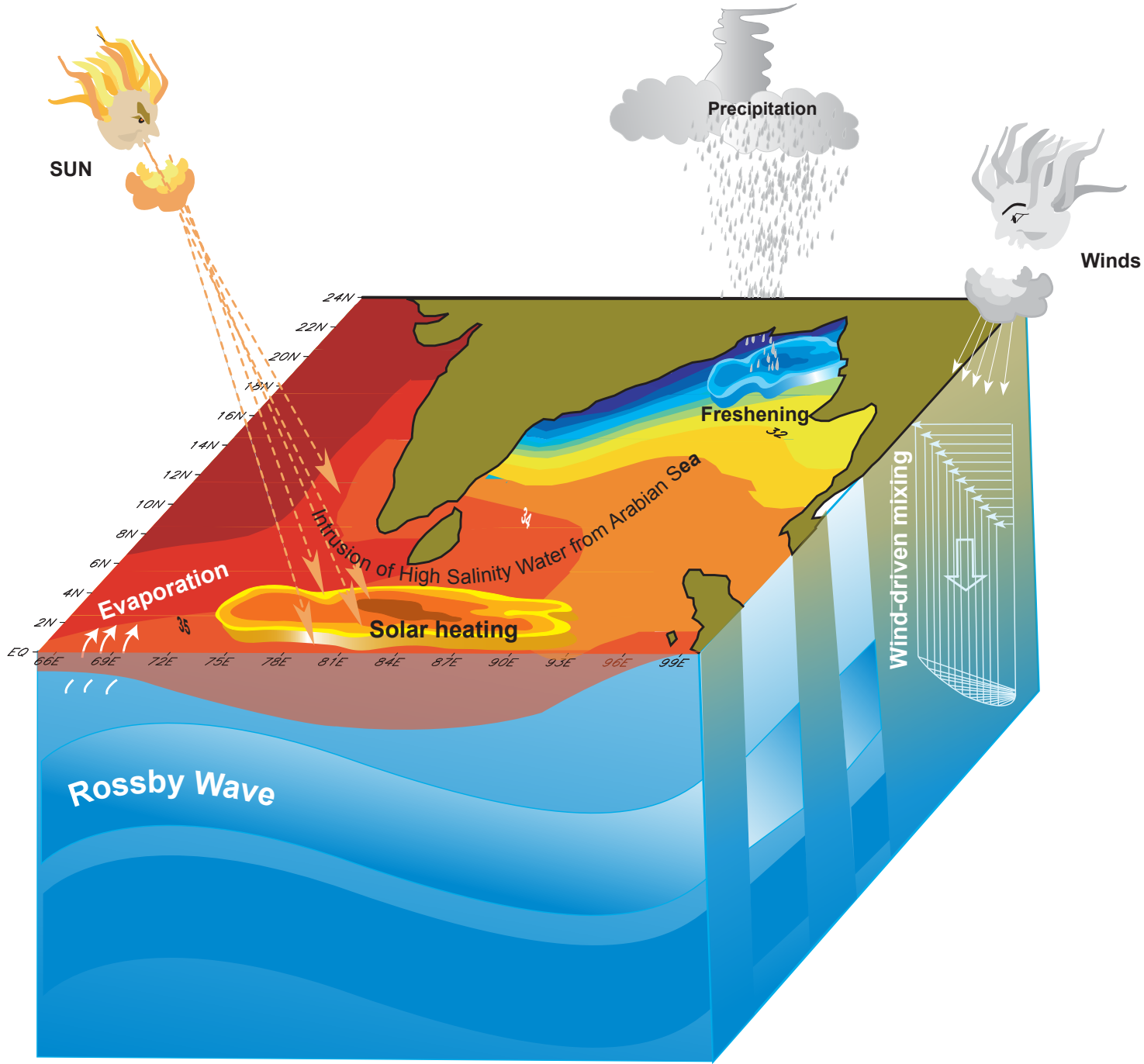

Figure A9. Schematic representation of local and remote forcings that influence the depth of the mixed layer. Colour shading is the climatological monthly mean salinity for August from WOA05 (Antonov et al., 2006) showing the intrusion of high salinity waters from the Arabian Sea. The local forcing that affect the MLD are the precipitation and river runoff, solar heating, and wind mixing. The remote forcings are the intrusion of high salinity waters from the Arabian Sea and propagation of Rossby waves. 
Acknowledgements. Authors are thankful to Director, CSIR-NIO, Goa, and Council of Scientific and Industrial Research (CSIR), New Delhi, for all the support and encouragement. We also acknowledge the help rendered by P. M. Muraleedharan, the late G.Nampoothiri and M. Nuncio in data collection. This work was supported by the Ministry of Earth Sciences (MoES), New Delhi under the programme BOB Process Studies (BOBPS). J. Narvekar acknowledges the Department of Science and Technology, New Delhi, for the fellowship. This is NIO contribution number 5613.

Edited by: R. Hood

\section{References}

Anitha, G., Ravichandran, M., and Sayanna, R.: Surface buoyancy flux in Bay of Bengal and Arabian Sea, Ann. Geophys., 26, 395400, 2008, http://www.ann-geophys.net/26/395/2008/.

Antonov, J. I., Locarnini, R. A., Boyer, T. P., Mishonov, A. V., and Garcia, H. E.: World Ocean Atlas 2005, Volume 2: Salinity, edited by: Levitus, S., NOAA Atlas NESDIS 62, US Government Printing Office, Washington DC, 182 pp., 2006.

Bathen, K. H.: On the seasonal changes in the depth of mixed layer in the north Pacific Ocean, J. Geophys. Res., 77, 7138-7150, 1972.

Boyer, T. P., Antonov, J. I.,Garcia, H., Johnson, D. R., Locarnini, R. A., Mishonov, A. V., Pitcher, M. T., Baranova, O. K., and Smolyar, I.: World Ocean Database 2005, Chapter 1: Introduction, edited by: Levitus, S., NOAA Atlas NESDIS 60, US Government Printing Office, Washington DC, 182 pp., 2006.

Brainerd, K. E. and Gregg, M. C.: Surface mixed and mixing layer depths, Deep-Sea Res. I., 42, 1521-1543, 1995.

Colborn, J. G.: The thermal structure of the Indian Ocean, International Indian Ocean Expedition Monographs 2, University Press of Hawaii, Honolulu, 1975.

de Boyer Montegut, C., Mignot. J., Lazar, A., and Cravatte, S.: Control of salinity on the mixed layer depth in the world ocean: 1. General description, J. Geophys. Res., 112, C06011, doi:10.1029/2006JC003953, 2007.

Gopalakrishna, V. V., Sadhuram, Y., and Ramesh Babu, V.: Variability of mixed layer depth in the northern Indian Ocean during 1977 and 1979 summer monsoon seasons, Indian J Mar. Sci., 17, 258-264, 1988.

Hastenrath, S. and Greischar, L. L.: Climatic atlas of the Indian Ocean, part-III, Upper-Ocean structure, USA, The University of Wisconsin Press, 247 pp., 1989.

Han, W., McCreary, J. P., and Kohler, K. E.: Influence of precipitation minus evaporation and Bay of Bengal rivers on dynamics, thermodynamics, and mixed layer physics in the upper Indian Ocean, J. Geophys. Res., 106, 6895-6916, 2001.

Kara, A. B., Rochford, P. A., and Hurburt, H. E.: Mixed layer depth variability over the global ocean, J. Geophys. Res., 108, 3079, doi:10.1029/2000JC000736, 2003.

Keerthi, M. G., Lengaigne, M. Vialard, J., de Boyer Montégut, C., and Muraleedharan, P. M.: Interannual variability of the Tropical Indian Ocean mixed layer depth, Clim. Dynam., 40, 743-759, 2012.
Levitus, S.: Climatological Atlas of the World Ocean, NOAA Professional paper 13, National Oceanic and Atmospheric Administration, Rockville Md, 173 pp., 1982.

Lukas, R. and Lindstrom, E.: The mixed layer of the western equatorial Pacific Ocean, J. Geophys. Res., 96, 3343-3357, 1991.

Levy, M., Shankar, D., Andre, J.-M., Shenoi, S. S. C., Durand, F., and de Boyer Monteguet, C.: Basin-wide seasonal evolution of the Indian Ocean's phytoplankton blooms, J. Geophys. Res., 112, C12014, doi:10.1029/2007JC004090, 2007.

Monterey, G. and Levitus, S .: Seasonal variability of mixed layer depth for the world ocean, NOAA atlas NESDIS 14, US Gov Printing Office, Washington DC, 87 figures, 96 pp., 1997.

Narvekar, J. and Prasanna Kumar, S .: Seasonal variability of the mixed layer in the central Bay of Bengal and associated changes in nutrients and chlorophyll, Deep-Sea Res. Pt. I, 53, 820-835, 2006.

Pond, S. and Pickard, G. L.: Introductory dynamical oceanography, Pergamon Press, New York, 241 pp., 1983.

Prasad, T. G.: Annual and seasonal mean buoyancy fluxes for the tropical Indian Ocean, Curr. Sci., 73, 667-674, 1997.

Prasad, T. G.: A comparison of mixed layer dynamics between the Arabian Sea and the Bay of Bengal: One dimensional model results, J. Geophys. Res., 109, C03035, doi:10.1029/2003JC002000, 2004.

Prasanna Kumar, S., Narvekar, J., Nuncio, M., Kumar, A., Ramaiah, N., Sardesai, S., Gauns, M., Fernandes, V., and Paul, J.: Is the biological productivity in the Bay of Bengal light limited?, Curr. Sci., 98, 1331-1339, 2010.

Rao, R. R. and Sivakumar, R.: Seasonal variability of near-surface thermal structure and heat budget of the mixed layer of the tropical Indian ocean from a new global ocean temperature climatology, J. Geophys. Res., 105, 995-1016, 2000.

Rao, R. R. and Sivakumar, R.: Seasonal variability of sea surface salinity and salt budget of the mixed layer of the north Indian Ocean, J. Geophys. Res., 108, 3009, doi:10.1029/2001JC000907, 2003.

Rao, R. R., Molinari, R. L., and Festa, J. F.: Evolution of the climatological near-surface thermal structure of the tropical Indian Ocean: Description of mean monthly mixed-layer depth and seasurface temperature, surface-current and surface meteorological fields, J. Geophys. Res., 94, 1081-10815, 1989.

Robinson, M. K., Baur, R. A., and Schroeder, E. H.: Atlas of North Atlantic-Indian Ocean monthly mean temperature and mean salinities of the surface layer, Naval Oceanographic Office Reference Publication 18, Department of the Navy, Washington DC, 203073, 213 pp., 1979.

Schneider, N. and Muller, P.: The meridional and seasonal structures of the mixed layer depth and its diurnal amplitude observed during the Hawaii-to-Tahiti Shuttle Experiment, J. Phys. Oeanogr., 20, 1395-1404, 1990.

Seo, H., Xie, S. P., Murtugudde, R., Jochum, M., and Miller, A.: Seasonal effects of Indian Ocean freshwater forcing in a regional coupled model, J. Climat., 22, 6577-6596, doi:10.1175/2009JCLI2990.1, 2009.

Shenoi, S. S. C., Shankar, D., and Shetye, S. R.: Difference in heat budgets of the nearsurface Arabian Sea and Bay of Bengal: Implications for the summer monsoon, J. Geophys. Res., 107, 3052, doi:10.1029/2000JC000679, 2002. 
Sprintall, J. and Tomczak, M.: Evidence of barrier layer in the surface layer of the tropics, J. Geophys. Res., 97, 7305-7316, 1992.

Subramanian, V.: Sediment load of Indian Rivers, Curr. Sci., 64, 928-930, 1993.

Thadathil, P., Muraleedharan, P. M., Rao, R. R., Somayajulu, Y. K., Reddy, G. V., and Revichandran, C.: Observed seasonal variability of barrier layer in the Bay of Bengal, J. Geophys. Res., 112, C02009, doi:10.1029/2006JC003651, 2007.

UNESCO: Technical papers in marine science, United Nations Educational, Scientific and Cultural Organization, Paris, 192 pp., 1981.

Vinayachandran, P. N.: Impact of physical processes on chlorophyll distribution in the Bay of Bengal, in Indian Ocean Biogeochemical Processes and Ecological Variability, edited by: Wiggert, J. D., Hood, R. R., Naqvi, S. W. A., Brink, K. H., and Smith, S. L., Americal Geophysical Union, Washington DC, doi:10.1029/2008GM000705, 2013.
Vinayachandran, P. N. and Mathew, S.: Phytoplankton bloom in the Bay of Bengal during the northeast monsoon and its intensification by cyclones, Geophys. Res. Lett., 30, 1572, doi:10.1029/2002GL016717, 2003.

Vinayachandran, P. N. and Yamagata, T.: Monsoon response of the sea around Sri Lanka: Generation of thermal domes and anticyclonic vortices, J. Phys. Oceanogr., 28, 1946-1960, 1998.

Vinayachandran, P. N., Murthy, V. S. N., and Ramesh, B. V.: Observations on barrier layer formation in the Bay of Bengal during summer monsoon, J. Geophys. Res., 107, 8018, doi:10.1029/2001JC00083, 2002.

Weller, R. A. and Farmer, D. M.: Dynamics of the ocean mixed layer, Oceans, 35, 46-55, 1992.

Wyrtki, K.: The thermal structure of the eastern Pacific Ocean, Deutsche Hydrographische Zeitschrift, Supplement A8, 6-84, 1964. 